\title{
The Risk Premium and Long-Run Global Imbalances *
}

\author{
YiLi Chien ${ }^{\dagger}$ \\ Federal Reserve Bank of St. Louis
}

\author{
Kanda Naknoi ${ }^{\ddagger}$ \\ Purdue University
}

March 15, 2012

\begin{abstract}
Our paper investigates whether the valuation effect caused by a large risk premium and a low risk-free rate can help to explain the enormous US current account and trade deficit observed in the past decade. To answer this question, we set up an endowment growth model in which investors are endowed with heterogeneous trading technologies. In our model, the average US investors load up more aggregate risk by investing in a risky asset abroad and issuing a risk-free asset. Thanks to the large risk premium as well as the low risk-free rate, the US can sustain a long-run trade deficit even as a debtor country. Quantitatively, we find that the valuation effect caused solely by the high risk premium and the low risk-free rate in our model, which is calibrated to match the external assets and liabilities of the US economy, can account for more than half of the observed trade deficit and current account deficit. Our results suggest that the current US trade deficit might not necessarily lead to net export increases or dollar depreciation in the future.

Keywords: Global Imbalances; External Account; Risk Premium; Asset Pricing; Limited Participation (JEL code: E21, F32, F41, G12)
\end{abstract}

${ }^{*}$ We would like to thank Harold Cole, Jonathan Heathcote, Hanno Lustig, Vincenzo Quadrini, Yi Wen and Eric Van Wincoop, as well as participants of seminars at Academia Sinica, Federal Reserve bank of St. Louis, University of Connecticut, University of Tokyo, and University of Virginia, for helpful discussions and comments. The views expressed are those of the individual authors and do not necessarily reflect official positions of the Federal Reserve Bank of St. Louis, the Federal Reserve System, or the Board of Governors.

${ }^{\dagger}$ Research Division, Federal Reserve Bank of St. Louis, P.O. Box 442, St. Louis, MO 63166-0442; Email: yilichien@gmail.com

${ }^{\ddagger}$ Department of Economics, Purdue University, 403 West State St., West Lafayette, IN 47907; Email: knaknoi@purdue.edu. 


\section{Introduction}

The debate on the sustainability of global imbalances originated in the persistent and large US current account deficit. The US current account deficit rose from 4\% of GDP in 2000 to $6 \%$ of GDP in 2005 and 2006. Historically, 5\% to 8\% current-account-deficit-to-GDP ratios in developing countries were followed by a sudden stop of capital inflows, a sharp currency depreciation and a current account reversal (Calvo (1998) ; Calvo, Izquierdo, and Talvi (2003)) $!^{1}$ A reversal of current account deficits and trade deficits following persistent and large external imbalances is in fact predicted by the intertemporal approach to the current account. Obstfeld and Rogoff (2000) and Obstfeld and Rogoff (2007) have predicted that a reversal of the US current account deficit is inevitable and the future US trade surplus requires the dollar real exchange rate to depreciate by as much as $50 \%$.

However, Gourinchas and Rey (2007a) have pointed out that the current account statistics and the intertemporal approach to the current account do not incorporate capital gains of external assets or the so-called valuation effect. The gap between current account statistics and trade balance statistics is equal to net factor income flows combined with unilateral transfers, which are quite modest for most countries, including the US. For this reason, the debate on the sustainability of the current account deficit becomes the debate on the sustainability of the trade deficit. Gourinchas and Rey (2007b) propose a new measure of global imbalances to take into account the changes of prices of US external assets and liabilities. They emphasize the short-run adjustment, and assume that the long-run return on US external assets and liabilities is identical. As a result, their work suggests that the estimated valuation effect results only from the short-run dollar depreciation, which has the same effect across types of assets. A subsequent study by Gourinchas, Rey, and Govillot (2010) confirms the large US long-run returns differential with updated data and offers a rare disaster model to account for the empirical finding. Quantitatively, the trade balance predicted by their model is $-0.72 \%$ of output in normal time, $1.53 \%$ of output during diaster periods, and overall $-0.18 \%$ unconditionally. Clearly, their model did not generate a large long-run trade deficit.

In this study, we examine the quantitative impact of valuation effects, which are solely caused

\footnotetext{
${ }^{1}$ The current account deficit in Mexico in 1994 and Thailand in 1996 prior to their balance of payments crises was 8\%. Argentina's current account deficit in 1998, prior to the 1999-2001 financial crisis, was 5\%.
} 
by a large risk premium and a low risk-free rate, not by exchange rates. Our valuation effect reflects different degrees of riskiness of assets held by US residents and residents in the rest of the world (ROW). The major distinction from Gourinchas, Rey, and Govillot (2010) is the sustainability of large trade deficits generated by our calibrated model. We build a multi-country general equilibrium model featuring heterogeneous portfolio choices across households. The world is an endowment growth economy, in which a consumption good is homogeneous and freely traded across borders with unit real exchange rate. The key feature is that households have heterogeneous trading technologies, as in Chien, Cole, and Lustig (2011). To be specific, a fraction of households are Mertonian traders, who can trade state-contingent claims and hence frequently adjust their portfolios in response to changes in the investment opportunity set. The remaining households are non-Mertonian traders holding fixed portfolios of equities and bonds. An additional feature is that the fraction of each type of traders varies across each country. Therefore, the overall trading technologies of one country are defined by the composition of the traders' pool across the population. Note that households in our model are completely rational subject to their trading technologies and borrowing constraints. In other words, their consumption Euler equations are always satisfied.

Intuitively, heterogeneous trading technologies generate differences in the portfolios held by Mertonian traders and those held by passive traders. Households with more sophisticated trading technologies take greater aggregate risk by holding a large fraction of equity in their portfolios, while households with a less sophisticated trading technology take a more cautious approach. Therefore, a large amount of risk could be concentrated in a relatively small group of traders because of the limitation in trading technologies. Thanks to the compensation for risk holdings, households with a large equity position ultimately earn a high rate of return on their portfolios, accumulate a greater amount of wealth and enjoy a high level of consumption. On the other hand, less sophisticated investors earn a low return on their portfolio, acquire a low level of wealth and consume little. Hence, heterogeneous trading technologies induce consumption and wealth dispersion. To understand the implication for international trade, consider aggregating all agents in each country. If a country loads up more aggregate risk than the ROW, then this country earns a higher average wealth return, consumes more than its output and runs a trade deficit, even in the long run. In our model, a higher degree of aggregate risk exposure of a country can result from: (i) a higher rate of equity market participation; and (ii) a larger fraction of equity in the portfolios 
held by equity market participants. Therefore, external balances are significantly associated with trading technologies and the scale of the risk premium.

In addition, our idea illustrates that the essential factor that decides the sustainability of trade deficits is the excess risk held by a country. If a country bears more aggregate risk than the ROW, its trade deficit can co-exist with a negative net external asset position. For example, US investors can load up risk while running a trade deficit, by issuing risk-free bonds and investing in equities abroad. In other words, there is no particular relationship between the net foreign asset position and the trade balance in the long run. Hence, focusing on the external net asset position might lead to a misleading conclusion regarding the adjustment of the trade deficit. Most importantly, an increase in the trade deficit might not necessarily lead to an equal increase in net exports in the future, and the magnitude of currency depreciation required to reduce the trade deficit might be small.

In the quantitative part, we calibrate the model to match the historically high equity premium as well as the low and stable risk-free rate. By introduction of heterogeneity in trading technologies, our calibrated model forces a small fraction of Mertonian traders to absorb a large amount of aggregate risk. Therefore, our benchmark model generates a $6.35 \%$ equity premium and a $2.16 \%$ risk-free return, which are quite close to the estimates in Guvenen (2009). ${ }^{2}$ Our calibration targets of the risk premium and the risk-free rate are conservatively chosen. In fact, our results will be enhanced if the model is calibrated to match a higher equity premium or a lower risk-free rate. In addition, the heterogeneity in trading technologies also makes the model flexible enough to characterize the asymmetric composition of asset holdings across the world. More specifically, by changing the idiosyncratic risk and the composition of the traders' pool across countries, the model could be calibrated to match the average debt-equity composition of the US external asset and liability position from 2000 to 2009. The quantitative results of our calibrated model show a large trade deficit in the long run. The US trade deficit is predicted to be $2.95 \%$ of output, which is more than one half of the average US trade deficit in 2000-2009. Our model predicts the average trade deficit in the long-run equilibrium, while the recent surge of US trade deficit might still reflect the

\footnotetext{
${ }^{2}$ In the asset pricing literature, the equity premium is generally considered at least higher than $6 \%$ and the risk-free rate is lower than $2 \%$. For examples, Guvenen (2009) shows that US equity premium is $6.17 \%$ and the risk-free rate is $1.94 \%$. Chien, Cole, and Lustig (2011) find that the equity premium is $7.53 \%$ and the risk-free rate is $1.05 \%$. According to Campbell and Cochrane (1999), the US equity premium and the US risk-free rate are $6.69 \%$ and $0.1 \%$ respectively. In the Table 2 of Alvarez and Jermann (2001), the equity premium is $6.18 \%$ and the risk-free rate is $0.8 \%$.
} 
transition path. During the transition, the trade deficit could be quite large since the US net asset position is deteriorating.

Our main contribution to the literature is the quantitatively large impact of the risk premium on global imbalances. Since the official current account statistics do not incorporate the valuation effect, our results imply that one half of the US current account deficit in the past decade is sustainable. For this reason, the risk premium, which has strong support in empirical studies, should be considered an important part of the valuation effect. The second contribution of our work is that our modeling approach provides a new theoretical framework to study various questions related to capital flows and the current account. Although the theoretical literature in open-economy macroeconomics has extensively studied portfolio choices, the risk premium generated by the existing studies falls short of the estimates in the empirical literature. Since the household's saving decision concerns not only the level of saving but also the composition of assets, incorporating a large risk premium into an open-macro model is essential for understanding the dynamics of current account. In this regard, our model is complementary to that of Mendoza, Quadrini, and Ros-Rull (2009), who consider the returns differential between a risky asset and a risk-free bond in a model with asymmetry in the degree of financial development. However, the absence of long-run output growth and aggregate shocks in their model results in a much smaller risk premium than ours.

The rest of the paper is organized as follows. The next section discusses related literatures. The first part of Section 3 illustrates our idea in a single equation. The rest of Section 3 provides the statistics of US external balances and decomposes US external positions. Section 4 describes the environment, the trading technologies and our model. The quantitative results as well as sensitivity analysis are listed in Section 5. Section 6 concludes our study.

\section{Related Literatures}

Our paper is motivated by an empirical literature that documents the large returns differential between US external assets and liabilities in the past few decades. The literature includes Obstfeld and Rogoff (2005), Meissner and Taylor (2006), Lane and Milesi-Ferretti (2007), Gourinchas and Rey (2007a) and Gourinchas, Rey, and Govillot (2010). In general, these papers find that the 
United States' external liabilities roughly pay $3 \%$ to $4 \%$ less than its external assets at annual rates of return. We consider these empirical findings as strong evidence suggesting that the US investors have loaded up more aggregate risk in external assets than liabilities. In addition, Gourinchas and Rey (2007a) document that the US finances risky investment abroad by issuing low-risk, short-run liabilities to the ROW in the past two decades.

However, Curcuru, Dvorak, and Warnock (2008) find that the US external assets do not necessarily yield higher returns than its liabilities, suggesting that the effect of returns differentials might be small. We consider that their results might not be suitable for our model for the following reasons. First, Curcuru, Dvorak, and Warnock (2008) only consider portfolio equity and debt securities and exclude the following types of assets: FDI, assets reported by nonbanking concerns, and assets reported by US banks and securities brokers. The omitted claims account for $60 \%$ of US external assets, and the omitted liabilities account for $50 \%$ of US external liabilities. Second, the data period is from 1994 to 2004, which is relatively too short to estimate long-run average returns. These estimated returns could be sensitive to the choice of sample period. Finally, the frequency of their data is monthly while our calibrated model operates at annual frequency. Many empirical studies have shown that most investors do not change their asset position or portfolio very often $]^{3}$ The return estimation from high frequency data, therefore, might not be suitable for studying the long-run behavior of the trade deficit and the current account.

A number of very recent theoretical studies have demonstrated that differences in the timevarying composition of asset portfolios of US investors and those of foreign investors play a role in international capital flows, such as Mendoza, Quadrini, and Ros-Rull (2009), Tille and van Wincoop (2010), Hnatkovska (2010), Devereux and Sutherland (2010), Angeletos and Panousi (2011) and Bacchetta and Benhima (2010). These papers are certainly related to this strand of research. Furthermore, Curcuru, Dvorak, and Warnock (2010) and Curcuru, Thomas, Warnock, and Wongswan (2011) provide evidence that US investors may be better than foreign investors at choosing country composition in their portfolios. Their work can be regarded as evidence that US investors are endowed with better trading technologies, which can be incorporated into our model by increasing the fraction of US Mertonian traders. However, we take a cautious approach

\footnotetext{
${ }^{3}$ There is strong empirical evidence suggesting that households do not change their asset allocations often. For example, these papers include Ameriks and Zeldes (2004), Brunnermeier and Nagel (2008), Calvet, Campbell, and Sodini (2009) and Alvarez, Guiso, and Lippi (2011)
} 
in our benchmark economy by assuming identical fractions of Mertonian traders in both countries. Alternatively, we consider the asymmetric fraction of Mertonian traders in subsection 5.5. The results show that the higher fraction of US Mertonian traders is, the higher is the trade deficit.

We make the following contributions to the literature. First, we illustrate that even when exchange rates do not adjust, the valuation effect can be quite large. We consider all the returns differentials between external assets and liabilities by allowing investors in different locations to load a different amount of risk. The different amount of risk comes from both equity-bond returns differentials and the composition of external assets and external liabilities. The large differential between equity-bond returns and composition of assets offers an explanation for the estimated returns differentials between external assets and external liabilities in Gourinchas and Rey (2007a) and Gourinchas, Rey, and Govillot (2010). However, the returns differentials are absent in the model of Gourinchas and Rey (2007b). For this reason, their estimated valuation effect is limited by zero trade balance in the long run. Our work is complementary to their work in the sense that the compensation for risk in our model increases the valuation effect by relaxing the constraint that the long-run trade balance must be zero.

Second, our theoretical approach is complementary to that of Mendoza, Quadrini, and Ros-Rull (2009), who build a portfolio choice model to illustrate that cross-country differences in financial development produce heterogeneity in the composition of portfolios. Their model shows that the asymmetric exposure to idiosyncratic risk caused by distinct financial development across countries leads to an equilibrium in which the financially developed country becomes a debtor while holding a positive net external position of risky assets. The differences between their work and ours are both in the focus as well as in the quantitative prediction. Specifically, their focus is the cause of the negative net external asset position of the US, but our focus is the quantitative impact of the US net external asset position on the trade balance and the current account. Hence, the scale of the risk premium is central to our analysis. The assumption of asymmetric trading technologies helps us match the large scale of the risk premium, while the risk premium in Mendoza, Quadrini, and Ros-Rull (2009) is less than 0.7\% in most cases considered. Caballero, Farhi, and Gourinchas (2008) explain global imbalances and low interest rates by a story of heterogeneous financial development. Our paper adds the consideration of the risk premium and emphasizes the trade deficit.

Finally, our work is also related to Engel and Rogers (2006), who argue that a slightly optimistic 
assumption of a higher US GDP growth rate relative to the ROW can justify the large current account deficit in US data. The idea is straightforward: If US present value of future income is greater due to the expected high US growth rate, then it is optimal for US households to borrow against the future, resulting in a trade deficit. Interestingly, our growth economy demonstrates a similar mechanism by endogenously producing an equilibrium risk-free rate that is lower than the GDP growth rate. In our case, the US can sustain the long-run trade deficit simply by issuing a risk-free bond to the ROW, because the risk-free return net of output growth rate turns negative. This observation also contributes to the sizable long-run US trade deficit predicted by our calibrated model.

\section{US External Account}

In this section, we decompose the US external asset position into the net external equity position and the net external bond position. In short, we classify assets into two types, namely equity and bonds. To highlight our idea and why such decomposition is central to our analysis, let us first

discuss the influence of asset returns on the net external asset position and the trade balance in the long run.

\subsection{Asset Returns, Net External Asset Position and Trade Balance}

Consider the following dynamics of the net external asset position:

$$
N F A_{t+1}=R_{t+1} N F A_{t}+N X_{t+1}
$$

where $N F A_{t}$ is the net external asset position at the end of period $t, R_{t+1}$ is the gross return on the net external assets from the end of period $t$ to the end of period $t+1$, and $N X_{t+1}$ is the net exports or the trade balance in the period $t+1$. We then normalize the quantity variables by output, because of the growth of output. We rewrite the dynamics of net asset position relative to output as follows:

$$
\frac{N F A_{t+1}}{Y_{t+1}} \frac{Y_{t+1}}{Y_{t}}=R_{t+1} \frac{N F A_{t}}{Y_{t}}+\frac{N X_{t+1}}{Y_{t+1}} \frac{Y_{t+1}}{Y_{t}}
$$


Consider the long-run stationary equilibrium in which $N F A_{t+1} / Y_{t+1}=N F A_{t} / Y_{t}$ and positive constant output growth $g=Y_{t+1} / Y_{t}$. Then the net exports become:

$$
g \frac{N X_{t+1}}{Y_{t+1}}=\left(g-R_{t+1}\right) \frac{N F A_{t}}{Y_{t}}
$$

Next, we assume realistically that the return on assets and that on liabilities could be different. This assumption marks the major difference between our model and that of Gourinchas and Rey (2007b). We denote the returns by $R_{t+1}^{a}$ and $R_{t+1}^{l}$, respectively. Let $F A_{t} / Y_{t}$ denotes the external asset position relative to output and $F L_{t} / Y_{t}$ denotes the external liability position relative to output. Hence,

$$
g \frac{N X_{t+1}}{Y_{t+1}}=\left(g-R_{t+1}^{a}\right) \frac{F A_{t}}{Y_{t}}-\left(g-R_{t+1}^{l}\right) \frac{F L_{t}}{Y_{t}} .
$$

where we assume $F A_{t} / Y_{t}$ and $F L_{t} / Y_{t}$ are invariant in a stationary equilibrium.

According to (2), we can predict the following patterns of the long-run net external asset position and the long-run trade balance.

1. If $R_{t+1}^{a}=R_{t+1}^{l}>g$, then

$$
\frac{N X_{t+1}}{Y_{t+1}} g=\left(g-R_{t+1}^{l}\right) \frac{N F A_{t}}{Y_{t}}
$$

Hence, in the absence of returns differentials between external assets and external liabilities, a negative net external asset position in the long-run must coexist with a positive trade balance. In contrast, if $R_{t+1}^{a}=R_{t+1}^{l}<g$, then the trade surplus must result from negative net external asset holdings.

2. If $R_{t+1}^{a}>R_{t+1}^{l}$ and $R_{t+1}^{a}>g$, then $N X_{t+1} / Y_{t+1}<0$ if and only if

$$
\left(R_{t+1}^{a}-g\right) \frac{F A_{t}}{Y_{t}}>\left(R_{t+1}^{l}-g\right) \frac{F L_{t}}{Y_{t}}
$$

In other words, a country can run a trade deficit in the long-run when the net return (net of output growth) on external assets is higher than the net return on external liabilities. The above condition may hold even when $N F A_{t} / Y_{t}=F A_{t} / Y_{t}-F L_{t} / Y_{t}<0$ and is particularly true if $R_{t+1}^{a}>g>R_{t+1}^{l}$.

Evidently, we cannot predict sign relationship between $N F A_{t} / Y_{t}$ and $N X_{t} / Y_{t}$ unless we take 
into account the valuation effect of $R_{t+1}^{a}, R_{t+1}^{l}$ and $g$. Of most importance, $R_{t+1}^{a}$ and $R_{t+1}^{l}$ depend on the portfolio choice of external assets and liabilities. In particular, our emphasis is on the returns differentials coming from the different degrees of risk of each asset class and how such returns differentials are affected by the portfolio choice. To evaluate our idea, the ideal approach is to calibrate our model to match the portfolio distribution across world-wide population. Unfortunately, the detailed portfolio data at the individual level are not available. At the aggregate level, the investment position database usually consists of holding of several types of assets, namely foreign direct investment (FDI), stock, bond and currency. However, we still face several challenges to evaluate the actual degree of risk holding in the external liabilities and assets. First, the actual composition of holding within each asset class may be quite different between external liabilities and assets. It could be the case that US investors prefer value stocks while foreign investors hold more growth stocks. In addition, the return on FDI is not identical to the stock return, and the returns on various types of bonds vary a great deal, from treasury securities to junk bonds. Finally, on the model side, we are not able to consider all types of assets available on the financial markets due to computational constraints.

To overcome these difficulties, we proceed with a simple idea: by allowing investors to hold a portfolio of a risky equity and a risk-free bond, we can replicate any desired risk structure observed in the data. In other words, we can use these two assets to replicate the observed portfolio returns as a simple way to account for different degrees of risk chosen by US investors and foreign investors. If US external assets load up more risk than its external liabilities, then the average return of external assets must exceed the average return on liabilities. In the following subsection, we describe how to decompose the US external asset and liability position, respectively, into the external risky equity and external risk-free bond in order to replicate the observed portfolio returns.

\subsection{Decomposition of US External Position}

We limit our attention to the US net asset position in 2000-2009, because the debate over the sustainability of global imbalances is concerned with this period. We measure all variables relative to US output, where output is defined as trade balance plus private consumption and government consumption. Our measure of output is equivalent to GDP excluding investment, as in the model.

To decompose the US net external asset position into the net external equity position and the 
net external bond position, we proceed in the following three steps. First, we calculate the US external asset and liability positions as a share of real output. See Appendix A for a detailed data description.

Second, we calculate the share of equity in the external asset position $\left(s_{U S}\right)$ and the share of equity in the external liability position $\left(s_{R O W}\right)$ such that the average return on US external assets and the average return on US external liabilities match the estimates in Gourinchas and Rey (2007a). As discussed above, assets in the BEA's database are issued by a large number of countries and they have different degrees of risk and returns, but equity and bonds in our calibrated model are assumed to be homogeneous across countries. Hence, the equity premium are the same across countries:

$$
E x R_{D}=E R_{D}-E R_{f}
$$

where $E R_{D}$ denotes the unconditional expected return on the equity, $E R_{f}$ denotes the unconditional expected return on the risk-free bond, and $E x R_{D}$ denotes the unconditional equity premium. Then, the implied equity shares need to satisfy the followings equations for external assets and liabilities, respectively:

$$
\begin{aligned}
s_{U S} E R_{D}+\left(1-s_{U S}\right) E R_{f} & =E R^{a}, \\
s_{R O W} E R_{D}+\left(1-s_{R O W}\right) E R_{f} & =E R^{l} .
\end{aligned}
$$

As we shall show later, our calibrated benchmark model produces a $6.35 \%$ equity premium and a $2.15 \%$ risk-free return, thus the return on equity is $8.50 \%$. In Gourinchas and Rey (2007a), the average return on the US external assets and the average return on the US external liabilities in the post-Bretton Woods period are 6.8\% and 3.5\%, respectively. As discussed in the introduction, the returns differential estimated by Gourinchas and Rey (2007a) is in line with several other empirical studies, which find that the returns differential is between $3 \%$ and $4 \%$. We substitute these returns into (3) and (4) to obtain $s_{U S}$ and $s_{R O W}$. Hence, $s_{U S}=0.73$ and $s_{R O W}=0.21$.

In the last step, we use the calculated $s_{U S}$ and $s_{R O W}$ to derive the US net external equity position and the US net external bond position as follows. 
1. US net external equity position:

$$
\frac{N E_{t}}{Y_{t}}=s_{U S} \frac{F A_{t}}{Y_{t}}-s_{R O W} \frac{F L_{t}}{Y_{t}}
$$

2. US net external bond position:

$$
\frac{N B_{t}}{Y_{t}}=\left(1-s_{U S}\right) \frac{F A_{t}}{Y_{t}}-\left(1-s_{R O W}\right) \frac{F L_{t}}{Y_{t}}
$$

Table I provides the average of the US external asset position, external liability position and balance of payments relative to output in 2000-2009. During 2000-2009, the average of the US external asset position is $107.11 \%$ of output. The average of the US external liability position is $133.46 \%$ of output. Substituting these statistics into (5) and (6) yields the net external equity position and the net external bond position as $50.39 \%$ and $-76.74 \%$ of output, respectively. Their sum, which is the US net external asset position, is $-26.35 \%$ of output. We report the balance of payments in the last three rows in Table I. We exclude unilateral transfers from our measure of the current account in order to capture only market transactions. On average, the US current account deficit in 2000-2009 is $4.88 \%$ of output. More than $100 \%$ of this sizable deficit is trade deficit, which amounts to $5.52 \%$ of output. The net factor income account is in surplus of $0.64 \%$ of output.

[Table 1 about here.]

\section{The Model}

This section offers a detailed description of the model.

\subsection{Environment}

Consider a multi-country world in which there are a large number of agents in each country. There is one endowment good, which is also the consumption good. The endowment good is homogeneous and freely traded across borders, hence the international relative price of the good, or the real exchange rate, is always one. Time is discrete, infinite and indexed by $t \in[0,1,2, \ldots)$. The initial 
period, $t=0$, is a planning period in which financial contracting takes place. There is aggregate uncertainty in the world and we do not assume country-specific productivity shocks to simplify our analysis. We use $z_{t} \in Z$ to denote the aggregate shock in period $t$, and let $z^{t}$ denote the history of aggregate shocks up to period $t$. The aggregate endowment of the entire world is given by:

$$
Y_{t}\left(z^{t}\right)=Y_{t-1}\left(z^{t-1}\right) g_{t}\left(z_{t}\right)
$$

where $g_{t}\left(z_{t}\right)$ is the stochastic growth rate of the endowment and is equivalent to the growth rate of world output. The share of each country in the world output is exogenously given and denoted by $\delta_{i}$. Hence, output of country $i$ is given by: $Y_{t}^{i}\left(z^{t}\right)=\delta_{i} Y_{t}\left(z^{t}\right)$, and $\sum_{i=1}^{I} \delta_{i}=1$. Output of each country is divided into two parts, namely diversifiable output and non-diversifiable output. The non-diversifiable portion is subject to idiosyncratic stochastic shocks in addition to aggregate shocks. Let $\eta_{t}^{i}$ denote the idiosyncratic shock in period $t$ of country $i$. Similarly, $\eta^{i, t}$ denotes the history of idiosyncratic shocks for the household $i$. The non-diversifiable portion of output is therefore given by: $\gamma^{i} Y_{t}^{i}\left(z^{t}\right) \eta_{t}^{i}$, where $\gamma^{i}$ denotes the share of non-diversifiable output in output of country $i$. The idiosyncratic events $\eta_{t}^{i}$ are i.i.d. across households within country $i$. Its mean is normalized to one. We use $\pi\left(z^{t}, \eta^{i, t}\right)$ to denote the unconditional probability of state $\left(z^{t}, \eta^{i, t}\right)$ being realized. The events are first-order Markov, and their probabilities are assumed to be in independent.

$$
\pi\left(z^{t+1}, \eta^{i, t+1} \mid z^{t}, \eta^{i, t}\right)=\pi\left(z_{t+1} \mid z_{t}\right) \pi\left(\eta_{t+1}^{i} \mid \eta_{t}^{i}\right)
$$

\subsection{Leverage and Assets Supply}

There are three type of assets available in this economy: equity, bonds, and contingent claims on aggregate shocks. All of these assets are claims to the diversifiable output. Note that this is still an incomplete market economy since there are no state-contingent assets on idiosyncratic shocks. The international financial market is assumed to be fully integrated.

We simply consider the equity of country $i$ as a leveraged claim on its aggregate diversifiable output $\left(\left(1-\gamma^{i}\right) Y_{t}^{i}\left(z^{t}\right)\right)$. The leverage ratio is constant over time and denoted by $\phi$. Let $B_{t}^{i}\left(z^{t}\right)$ denote the supply of a one-period risk-free bond in period $t$ in country $i$ and $W_{t}^{i}\left(z^{t}\right)$ denote the price of a claim to country $i^{\prime} s$ aggregate diversifiable output in period $t$. With a constant leverage 
ratio, the total supply of $B_{t}^{i}\left(z^{t}\right)$ has to be adjusted such that

$$
B_{t}^{i}\left(z^{t}\right)=\phi\left[W_{t}^{i}\left(z^{t}\right)-B_{t}^{i}\left(z^{t}\right)\right]
$$

By the equation above, the aggregate diversifiable output can be decomposed into the interest payment to bond holders and payouts to shareholders, and the total payouts, $D_{t}^{i}\left(z^{t}\right)$, is given by

$$
D_{t}^{i}\left(z^{t}\right)=\left(1-\gamma^{i}\right) Y_{t}^{i}\left(z^{t}\right)-R_{t, t-1}^{f}\left(z^{t-1}\right) B_{t-1}^{i}\left(z^{t-1}\right)+B_{t}^{i}\left(z^{t}\right)
$$

where $R_{t, t-1}^{f}\left(z^{t-1}\right)$ denotes the risk-free rate at period $t-1$. Note that $B_{t}^{i}\left(z^{t}\right)$ across each country $i$ is essentially identical, since it pays the same risk-free return, $R_{t+1, t}^{f}\left(z^{t}\right)$. For simplicity, our model assumes a constant supply of shares. As a result, if a firm reissues or repurchases shares of equity, it must be reflected by $D_{t}^{i}\left(z^{t}\right)$ in our model. Simply speaking, $D_{t}^{i}\left(z^{t}\right)$ includes both the cash dividends and net repurchases.

Traders who invest a fraction $\phi /(1+\phi)$ of their wealth in bonds and the rest in equity hold the market portfolio, which is identical to holding a claim to aggregate output. We denote the value of the equity (a claim to payouts $\left.D_{t}^{i}\left(z^{t}\right)\right)$ by $V_{t}^{i}\left(z^{t}\right) . R_{t, t-1}^{i, d}\left(z^{t}\right)$, the gross return of country $i^{\prime} s$ equity is therefore given by

$$
R_{t, t-1}^{i, d}\left(z^{t}\right)=\frac{D_{t}^{i}\left(z^{t}\right)+V_{t}^{i}\left(z^{t}\right)}{V_{t-1}^{i}\left(z^{t-1}\right)} .
$$

As for the state-contingent claim, we denote the price of a unit claim to the final good in aggregate state $z^{t+1}$ acquired in aggregate state $z^{t}$ by $Q_{t}\left(z_{t+1}, z^{t}\right)$.

\subsection{Trading Technologies}

A trading technology is defined as restrictions on portfolios in terms of the menu and composition of assets that a household can implement in any given period. Our model assumes two types of trading technologies, Mertonian trading technologies and non-Mertonian trading technologies. Mertonian traders can trade state-contingent claims on aggregate shocks. Therefore, they can optimally adjust their portfolio choice in response to the change of the investment opportunity set. They face no restrictions on their portfolio choice except they cannot trade a claim contingent on the idiosyncratic shocks. The menu of assets in non-Mertonian trading technologies consists only 
of equity and bonds, excluding all state-contingent claims. In addition, non-Mertonian traders are assumed to have a fixed equity target share in their portfolio and to rebalance their portfolio in order to achieve the target equity share every period. There is a special type of non-Mertonian traders, who hold zero equity target share. Since they do not participate in the equity market at all, we call them non-participants. As for those whose trading strategy consists of a positive fixed equity target share, we refer to them as non-Mertonian equity traders.

Non-Mertonian trading technologies differ from the optimal strategy along two dimensions. First, non-Mertonian traders cannot actively change the share of equity in their portfolio in response to changes in the market price of risk. To put it simply, they miss the market timing. As a result, they only choose the level of saving while their portfolio return is given by the fixed trading strategy. Secondly, we assume that the average equity share of non-Mertonian traders tends to be lower than the optimal level. As a result, these non-Mertonian traders are less exposed to the aggregate risk and hence earn a lower average return on their portfolio. In other words, they partly forgo the risk premium. These two differences in trading strategy create a sub-optimal consumption-savings choice along with the distorted asset allocation. Therefore, the consumption variation caused by the sub-optimal trading strategies is closely associated with the level of the risk premium as well as the variation of the risk premium.

We denote the fraction of traders in terms of the value of their non-diversifiable income or human wealth in each country $i$ by $\mu_{i}^{j}$, where $j \in\{m e, e t, n p\}$ represents Mertonian traders, nonMertonian equity traders and non-participants, respectively.

\subsection{Household's Problem}

Preferences All households have identical preferences. A household in country $i$ ranks the consumption plan, $\left\{c^{i}\right\}$, by the following equation

$$
U\left(\left\{c^{i}\right\}\right)=\sum_{t=1}^{\infty} \beta^{t} \sum_{\left(z^{t}, \eta^{i, t}\right)} \frac{c_{t}^{i}\left(z^{t}, \eta^{i, t}\right)^{1-\alpha}}{1-\alpha} \pi\left(z^{t}, \eta^{i, t}\right)
$$

where $\alpha$ denotes the coefficient of relative risk aversion, $\beta$ is the time discount factor and $c_{t}^{i}\left(z^{t}, \eta^{i, t}\right)$ denotes the household's consumption in state $\left(z^{t}, \eta^{i, t}\right)$. All households are ex-ante identical except in their trading technologies, which are reflected in their budget constraints. 
Budget Constraint of Mertonian Traders Consider a Mertonian trader in country $i$ entering the period with a net financial wealth $\sum_{j} a_{t}^{i, j}\left(z^{t}, \eta^{i, t-1}\right)$, where $a_{t}^{i, j}\left(z^{t}, \eta^{i, t-1}\right)$ denotes the total assets from country $j$ held by households in country $i$ in period $t$ given the history $\left(z^{t}, \eta^{i, t-1}\right)$. Note that the net financial wealth is not spanned by the realization of idiosyncratic shocks, $\eta_{t}^{i}$, since there are no contingent claims on idiosyncratic shocks. Otherwise, Mertonian traders face no restrictions on asset trading. At the end of the period, this trader buys securities in financial markets (statecontingent claims $\widehat{a}_{t}^{i, j}\left(z^{t+1}, \eta^{i, t}\right)$ issued by country $j$, risk-free bonds issued by country $j, b_{t}^{i, j}\left(z^{t}, \eta^{i, t}\right)$, and equity shares of country $\left.j, s_{t}^{i, j}\left(z^{t}, \eta^{i, t}\right)\right)$ and consumption $c_{t}^{i}\left(z^{t}, \eta^{i, t}\right)$ in the goods markets subject to this one-period budget constraint:

$$
\begin{aligned}
& \sum_{z^{t+1} \succ z^{t}} \sum_{j} Q_{t+1}\left(z_{t+1}, z^{t}\right) \widehat{a}_{t+1}^{i, j}\left(z^{t+1}, \eta^{i, t}\right) \pi\left(z_{t+1} \mid z_{t}\right)+\sum_{j} s_{t}^{i, j}\left(z^{t}, \eta^{i, t}\right) V_{t}^{j}\left(z^{t}\right)+\sum_{j} b_{t}^{i, j}\left(z^{t}, \eta^{i, t}\right) \\
& +c_{t}^{i}\left(z^{t}, \eta^{i, t}\right) \leq \sum_{j} a_{t}^{i, j}\left(z^{t}, \eta^{i, t-1}\right)+\gamma^{i} Y_{t}^{i}\left(z^{t}\right) \eta_{t}^{i}, \text { for all } z^{t}, \eta^{i, t},
\end{aligned}
$$

where $Q_{t+1}\left(z_{t+1}, z^{t}\right)$ denotes the price of a unit contingent claim to the final good in aggregate state $z_{t+1}$ acquired in aggregate state $z^{t} 4^{4}$ The agent's net financial wealth, $\sum_{j} a_{t}^{i, j}\left(z^{t}, \eta^{i, t-1}\right)$, in state $\left(z^{t}, \eta^{i, t}\right)$, is given by the payoffs of his state-contingent claim acquired last period, the payoffs from his equity position, and the risk-free bond payoffs:

$$
\begin{aligned}
\sum_{j} a_{t}^{i, j}\left(z^{t}, \eta^{i, t-1}\right) & =\sum_{j} \widehat{a}_{t}^{i, j}\left(z^{t}, \eta^{i, t-1}\right)+\sum_{j} s_{t-1}^{i, j}\left(z^{t-1}, \eta^{i, t-1}\right)\left[D_{t}^{j}\left(z^{t}\right)+V_{t}^{j}\left(z^{t}\right)\right] \\
& +\sum_{j} R_{t, t-1}^{f}\left(z^{t-1}\right) b_{t-1}^{i, j}\left(z^{t-1}, \eta^{i, t-1}\right) .
\end{aligned}
$$

Note that the total equity share of each country $i, \sum_{i} s_{t}^{i, j}$, is normalized to be 1.

Budget Constraint of Non-Mertonian Traders Households with non-Mertonian trading technologies can only access equities and bonds. In addition, all non-Mertonian traders are assumed to adopt a time-invariant portfolio choice, which is described by the equity share of each country $i$ in their portfolio. This equity share is denoted by $\omega=\left\{\omega^{i}\right\}_{i=1}^{I}$. Hence, we can denote their

\footnotetext{
${ }^{4}$ Notice that the price of a claim to aggregate output is independent of the country of issuance, since there are no country specific shocks on output.
} 
portfolio return as:

$$
R_{t+1, t}^{p, \omega}\left(z^{t}\right)=\sum_{j} \omega^{j} R_{t, t-1}^{j, d}\left(z^{t}\right)+\left(1-\sum_{j} \omega^{j}\right) R_{t, t-1}^{f}\left(z^{t-1}\right) .
$$

In order to reach a constant equity share, $\omega$, defined in their portfolio, they need to rebalance their portfolio to hit the target equity share $\omega^{j}$ for each country at each period.

Consider a country $i^{\prime} s$ non-Mertonian equity household starting with a net financial wealth $\sum_{j} a_{t}^{i, j}\left(z^{t}, \eta^{i, t-1}\right)$ in the beginning of period $t$. During the period, this household receives nondiversifiable income, $\gamma^{i} Y_{t}^{i}\left(z^{t}\right) \eta_{t}^{i}$ and consumes $c_{t}^{i}\left(z^{t}, \eta^{i, t}\right)$ in the goods markets. At the end of period $t$, the household buys equity shares, $s_{t}^{i, j}\left(z^{t}, \eta^{i, t}\right)$ and risk-free bonds, $b_{t}^{i, j}\left(z^{t}, \eta^{i, t}\right)$ subject to a fixed target portfolio equity share $\omega$. We denote the asset holdings at the end of period $t$ by:

$$
a e_{t}^{i}\left(z^{t}, \eta^{i, t}\right) \equiv \sum_{j} s_{t}^{i, j}\left(z^{t}, \eta^{i, t}\right) V_{t}^{j}\left(z^{t}\right)+\sum_{j} b_{t}^{i, j}\left(z^{t}, \eta^{i, t}\right)
$$

where

$$
\begin{aligned}
\omega^{j} & =\frac{s_{t}^{i, j}\left(z^{t}, \eta^{i, t}\right) V_{t}^{j}\left(z^{t}\right)}{a e_{t}^{i}\left(z^{t}, \eta^{i, t}\right)} \\
1-\sum_{j} \omega^{j} & =\frac{\sum_{j} b_{t}^{i, j}\left(z^{t}, \eta^{i, t}\right)}{a e_{t}^{i}\left(z^{t}, \eta^{i, t}\right)}
\end{aligned}
$$

In addition, the return on this fixed-weight portfolio is defined as in $(10)$. The flow budget constraint is therefore given by:

$$
a e_{t}^{i}\left(z^{t}, \eta^{i, t}\right) \leq a e_{t-1}^{i}\left(z^{t-1}, \eta^{i, t-1}\right) R_{t, t-1}^{p, \omega}\left(z^{t-1}\right)+\gamma^{i} Y_{t}^{i}\left(z^{t}\right) \eta_{t}^{i}-c_{t}^{i}\left(z^{t}, \eta^{i, t}\right) \text {, for all } z^{t}, \eta^{i, t}
$$

Finally, for the budget constraint of non-participants, set the equity share $\omega$ to zero vector. In addition, all households are subject to a solvency constraint, which is $\sum_{j} a_{t}^{i, j}\left(z^{t}, \eta^{i, t-1}\right) \geq 0$. The details of the household problem and its associated Euler equations are in Appendix B. 


\subsection{Aggregation}

We start with the aggregate budget constraint of country $i$, which can be obtained by summing the flow budget constraint (Equations $(8)$ and (12) ) across all types of households in country $i$. The idiosyncratic risks across households offset each other by applying the law of large numbers to the continuum population. Let the aggregate variable of country $i$ be denoted by an upper case, $X_{t}^{i}\left(z^{t}\right)=\sum_{j=m e, e t, n p} \sum_{\eta^{i, t}} \mu_{i}^{j} x_{t}^{i}\left(z^{t}, \eta^{i, t}\right) \pi\left(\eta^{i, t}\right)$. The aggregate budget constraint of country $i$ is therefore given by

$$
\begin{aligned}
& \sum_{z^{t+1} \succ z^{t}} \sum_{j} Q_{t+1}\left(z_{t+1}, z^{t}\right) \widehat{A}_{t+1}^{i, j}\left(z^{t+1}\right) \pi\left(z_{t+1} \mid z_{t}\right)+\sum_{j} S_{t}^{i, j}\left(z^{t}\right) V_{t}^{j}\left(z^{t}\right)+\sum_{j} B_{t}^{i, j}\left(z^{t}\right) \\
\leq & \sum_{j} A_{t}^{i, j}\left(z^{t}\right)+\gamma^{i} Y_{t}^{i}\left(z^{t}\right)-C_{t}^{i}\left(z^{t}\right), \text { for all } z^{t}
\end{aligned}
$$

and the aggregate asset holdings of country $i$ at period $t$

$$
\sum_{j} A_{t}^{i, j}\left(z^{t}\right)=\sum_{j} \widehat{A}_{t-1}^{i, j}\left(z^{t}\right)+\sum_{j} S_{t-1}^{i, j, D}\left(z^{t-1}\right) V_{t-1}^{j}\left(z^{t}\right) R_{t, t-1}^{j, d}\left(z^{t}\right)+\sum_{j} R_{t, t-1}^{f}\left(z^{t-1}\right) B_{t-1}^{i, j}\left(z^{t-1}\right) .
$$

From the above aggregate budget constraint of country $i$, we can derive the dynamic equation of net external assets. (see Appendix C)

$$
N F A_{t+1}^{i}\left(z^{t+1}\right)=R_{t+1}\left(z^{t+1}\right) N F A_{t}^{i}\left(z^{t}\right)+Y_{t+1}^{i}\left(z^{t+1}\right)-C_{t+1}^{i}\left(z^{t+1}\right)
$$

where $R_{t+1}\left(z^{t+1}\right)$ is the gross return on external assets. Equation 14 is a stochastic version of Equation (1).

\subsection{Asset Pricing and External Accounts}

Next, we explain the implications of our model for asset pricing as well as the external account.

Asset Pricing In our model, there are two key frictions to match the low risk-free rate and the high risk premium observed in the data. The first friction is the incomplete market with respect to idiosyncratic risk. It is well known that incomplete market models can produce reasonable risk-free rate implications in a growing economy. The second friction, limited participation, combined with 
non-Mertonian trading technologies of some market participants, produces a high equity premium by concentrating the aggregate risk among Mertonian traders. This is in line with Chien, Cole, and Lustig (2011), but they only consider a closed economy. Our paper extends the model into a multi-country economy and studies the determination as well as the consequences of global imbalances.

External Accounts In addition, the asymmetric trading technologies across countries with respect to the market participation rate and the composition of trader pools generate heterogeneous portfolio holdings across countries. A country with better trading technologies can take more aggregate risk by holding a larger fraction of equity while others take a more cautious approach by holding a greater fraction of risk-free assets. We also consider asymmetric idiosyncratic risks across countries. Households who face greater idiosyncratic risks accumulate more wealth according to precautionary saving motivation, implying a country with higher idiosyncratic risks tends to run a positive net asset position. This channel operates in the same way as Mendoza, Quadrini, and Ros-Rull (2009).

\subsection{Competitive Equilibrium}

A competitive equilibrium for this economy is defined in a standard way. It consists of a list of bond, equity, and state-contingent claims holdings; a consumption allocation; and a list of bond, equity, and state-contingent prices such that: (i) given these prices, a trader's asset and consumption choices maximize her expected utility subject to the budget constraints, the solvency constraints, and the constraints on trading technologies, and (ii) all asset markets clear.

\section{Quantitative Results}

This section starts with the discussion of model calibration. In the following subsections, we evaluate our calibrated model to examine the extent to which our model can account for the US external balances, especially with respect to the trade balance. We achieve this goal by three steps. To illustrate the intuition of our model, we first consider a symmetric two-country model, in which both countries have identical trading technologies and an identical idiosyncratic shock process. 
Then, we consider a benchmark model, which is calibrated to match several key features of asset compositions in US external accounts. In the Subsection 5.4, we demonstrate the importance of the risk premium to our results by considering a model without the aggregate risk, in which the equity premium is zero by construction. The last subsection displays the results of sensitivity analyses on the change in the composition of Mertonian traders and non-participants.

\subsection{Calibration}

We consider a two-country version of our model. Country 1, or the home country, is the United States (US) and Country 2, or the foreign country, is the ROW. The size of each country is measured by its share in world GDP. Table II displays country size together with other parameter values used in all cases.

The US share of world GDP is 33\%, although the actual US GDP share from the US Department of Agriculture's ERS Database in 1980-2009 is 27\% on average. The reason is that our hypothetical world does not comprise all countries. To be precise, our hypothetical world consists of 48 countries, which are OECD countries, large developing countries such as China and India, and medium-size developing countries. These 48 countries account for $83 \%$ of the actual world GDP in 1980-2009. Thus, the US GDP share in our hypothetical world adjusts to $33 \%$.

Our calibration strategy of aggregate shocks and idiosyncratic shocks is based on Alvarez and Jermann (2001). Aggregate shocks are calibrated into a two state first order Markov Chain with the first aggregate state as a recession and the second aggregate state as an expansion. Since there are only two aggregate states in our calibrated economy, the two assets, the equity and the risk-free bond, are sufficient to replicate any return of aggregate state-contingent claims. We drop the redundant state-contingent assets in our calibrated model. The stochastic aggregate output growth process is calibrated by four statistics: (i) the relative frequency between expansion and recession; (ii) the average growth rate of consumption per capita; (iii) the standard deviation of the growth rate of consumption per capita; and (iv) the first order auto-correlation of the growth rate of consumption per capita.

Expansions occur more often than recessions, the frequency of recessions is set to $27.4 \%$ as in Alvarez and Jermann (2001). The aggregate shocks are assumed to be i.i.d, given the fact that the growth rate of consumption is hard to predict (see the empirical support by Neely, Roy, and 
Whiteman (2001)). We also verify this assumption in our data by showing that the first order auto-correlation of the growth rate of real consumption per capita is not statistically different from zero for most countries. Specifically, we obtain the first order auto-correlation of country-specific growth rates of real consumption per capita by regressing the growth rates of real consumption per capita on its one-period lag and a constant. We find that the coefficient of the lag term is statistically not different from zero at $1 \%$ significance level for 42 out of 48 countries.

The average output growth rate and its standard deviation are $2.54 \%$ and $3.02 \%$ in our data set. Please see Appendix $\mathrm{D}$ for details. As a result, the transition probability of aggregate shocks is calibrated to

$$
\pi\left(z^{\prime} \mid z\right)=\left[\begin{array}{ll}
0.2740 & 0.7260 \\
0.2740 & 0.7260
\end{array}\right]
$$

and the average growth rate of output in the recession state and the expansion state is as follows: $z_{L}=0.9762, z_{H}=1.0440$.

We also consider a two state first order Markov Chain for idiosyncratic shocks. The first state is low and the second state is high. Following Storesletten, Telmer, and Yaron (2004) and Storesletten, Telmer, and Yaron (2007), we calibrate this shock process by two moments, namely the standard deviation of idiosyncratic shocks and the first order auto-correlation of the shocks respectively, except we eliminate the counter-cyclical variation in idiosyncratic risk. The Markov process for the $\log$ of non-diversified income share, $\log \eta$, has a standard deviation of 0.71 , and its auto-correlation is 0.89 . The transition probability is given by:

$$
\pi\left(\eta^{\prime} \mid \eta\right)=\left[\begin{array}{ll}
0.9450 & 0.0550 \\
0.0550 & 0.9450
\end{array}\right]
$$

The two states of idiosyncratic shocks, the mean of which is normalized to 1 , are $\eta_{L}=0.3894$, and $\eta_{H}=1.6106$.

Note that we do not have good sources for the idiosyncratic shock process for the ROW. As we shall show later, we calibrate the idiosyncratic shock process for the ROW to approximate the composition of the US external asset and liability position. Our calibration in fact indicates that the volatility of the ROW idiosyncratic process is slightly larger than that of the US, which is consistent with the finding of Mendoza, Quadrini, and Ros-Rull (2009). 
All households in the world have the same CRRA preference. Since this is a growth economy with $2.54 \%$ average growth rate, we set the time discount factor $\beta=1$, given the annual calibration of our model. The risk aversion rate $\gamma$ is set to be 6 in order to produce a high risk premium in our benchmark calibration. Following Chien, Cole, and Lustig (2011), the fraction of diversifiable output is set to be $10 \%$, which is also close to $11.25 \%$ set by Mendoza, Quadrini, and Ros-Rull (2009).$^{5}$ As shown in Section 4, equity in our model is simply a leveraged claim to diversifiable income. In the Flow of Funds, the ratio of corporate debt to net worth is roughly 0.65, suggesting a leverage parameter of 2. Nevertheless, the study by Cecchetti, Lam, and Mark (1990) reports that the standard deviation of the growth rate of dividends is at least 3.6 times that of aggregate consumption, suggesting that the appropriate leverage level is over 3. Following Abel (1999), Bansal and Yaron (2004) and Chien, Cole, and Lustig (2011), the leverage ratio parameter is set to be 3 in the US. For simplicity, leverage ratios are assumed to be the same across countries, implying equities of all countries are identical.

[Table 2 about here.]

\subsection{Symmetric Cases}

To illustrate the mechanism of our model, we start with a symmetric version, in which the composition of traders and the idiosyncratic shock process are identical in the home country and the foreign country. In this symmetric version of the model, we consider three quantitative experiments, which are different according to the traders' pool.

1. Experiments 1: The pool of traders consists of $100 \%$ Mertonian traders in both countries.

2. Experiments 2: The pool of traders consists of 5\% Mertonian traders and $95 \%$ non-Mertonian equity traders in both countries. The equity target share of non-Mertonian traders, $\omega$, is assumed to be $25 \%$. Hence, the non-Mertonian equity traders hold the market.

3. Experiments 3: The pool of traders consists of $5 \%$ Mertonian traders, $25 \%$ non-Mertonian traders and $70 \%$ of non-participants in both countries. The non-Mertonian equity traders are assumed to hold the market portfolio $(\omega=25 \%)$.

\footnotetext{
${ }^{5}$ Our result is robust to the variation in fraction of diversifiable output.
} 
Symmetric Cases: Quantitative Results The first panel of Table III reports the asset pricing results of all experiments. We report the equity premium $E\left(R^{D}-R^{f}\right)$, the standard deviation of excess return $\sigma\left(R^{D}-R^{f}\right)$, the Sharpe ratio on equity, the average risk-free rate $E\left(R^{f}\right)$ and the standard deviation of the risk-free rate $\sigma\left(R^{f}\right)$. The second panel reports the wealth return and the portfolio choice of each type of traders. Specifically, it reports the following: the average excess wealth return for Mertonian equity traders and non-Mertonian equity traders, denoted by $E\left(R_{W}-R_{f}\right)_{M}$ and $E\left(R_{W}-R_{f}\right)_{E T}$, respectively; the average equity share of portfolios for Mertonian traders and non-Mertonian equity traders, $E(\omega)_{M}$ and $E(\omega)_{E T}$ respectively; and the same statistics at the country level. $E\left(R_{W}-R_{f}\right)_{U S}$ and $E\left(R_{W}-R_{f}\right)_{R O W}$ denote the average total wealth return in the US and the ROW. Similarly, $E(\omega)_{U S}$ and $E(\omega)_{R O W}$ stand for the average equity share of the US and the ROW.

The last panel reports the US external balances statistics in percentage of US output. It is important to note that the current account in our model is different from the official current account statistics. To be precise, our theoretical current account include capital gains or capital losses as well as payments of dividends and interest earnings, but the official current account statistics include only payments of dividends and interest earnings. To illustrate the quantitative impacts of capital gains or the valuation effect on the current account, we compute the official version of the current account, denoted by $C A^{o}$, by adding net dividend payments and net interest income payments to the trade balance. In order to compute the net factor income account (NFIA), a dividend process is necessary. For this model economy, the dividend process is assumed as a version of leveraged aggregate consumption, with dividend growth determined by the following equation

$$
\Delta \ln \operatorname{Div}-E(\Delta \ln D i v)=\lambda[\Delta \ln C-E(\Delta \ln C)]
$$

Following Abel (1999), the leverage parameter $\lambda$ is assumed to be 3 . We report the following statistics in the last panel: the average trade balance, $E\left(\frac{T B}{Y}\right)_{U S}$, the average current account, $E\left(\frac{C A}{Y}\right)$, the average official current account, $E\left(\frac{C A^{o}}{Y}\right)$, the average NFIA, $E\left(\frac{N F I A}{Y}\right)$, the average net external equity position, $E\left(\frac{N e t E q u i t y}{Y}\right)_{U S}$, the average net external bond position, $E\left(\frac{N e t B o n d}{Y}\right)_{U S}$, and the net asset position, $E\left(\frac{\text { NetAsset }}{Y}\right)_{U S}$. All of them are reported as percentage of output.

In the first experiment, Mertonian traders have to hold the market portfolio in order to clear the asset market given that all households are endowed with identical trading technologies. The 
equilibrium prices must adjust such that holding the market portfolio is the optimal portfolio choice. This experiment is similar to the one by Krusell and Smith (1998) except that ours is an endowment economy. Since all households face idiosyncratic risk, the precautionary saving motive leads to a low risk-free rate of $3.26 \%$, as reported in Table III $\left.\right|^{6}$ The risk-free rate is constant due to the non-predictable consumption growth rate. In addition, the risk premium is only $2.38 \%$, reflecting the equity premium puzzle shown by Mehra and Prescott (1985). To summarize, with identical trading technologies across the population, the asset pricing result of our economy coincides with that of standard macroeconomic models.

In the second experiment, we replace $95 \%$ of traders with non-Mertonian equity traders, who are assumed to hold the market portfolio. The second column of Table III reports the results. This result suggests that the equilibrium allocations and prices of the second experiment are identical to those of the first experiment. The intuition is straightforward. Given the equilibrium prices of Experiment 1, the portfolio choice of non-Mertonian equity traders is an optimal one (market portfolio) and Mertonian traders behave exactly the same as in the Experiment 1. No agents change their decision rules regarding consumption and investment. Consequently, the equilibrium allocations and prices are unchanged. In fact, this result is proven analytically by Krueger and Lustig (2010). From this experiment, we learn that even though Mertonian traders have superior trading technologies, they take no advantage if other traders do not make investment mistakes. As a result, there is no difference between Mertonian and non-Mertonian equity traders. However, this will not be the case if we replace a fraction of non-Mertonian equity traders with non-participants, who deviate from the optimal portfolio choice. We demonstrate this in the third experiment.

Finally, in the third experiment, we decrease the fraction of non-Mertonian equity traders to $25 \%$ and add $70 \%$ of non-participants, while keeping $5 \%$ of Mertonian traders. The third column of Table III reports the results. The risk-free rate becomes even lower, $2.13 \%$, and still remains almost constant with only $0.11 \%$ standard deviation. At the same time, the equity premium increases to $6.69 \%$, which is close to that in the data. The second panel shows that Mertonian traders realize a much higher wealth return, 5.33\%, by taking a large fraction of equity in their portfolio, 79\%. The intuitions for these results can be understood as follows. First, the portfolio choice of non-participants clearly cannot be optimal given the prices of the previous experiments.

\footnotetext{
${ }^{6}$ The risk-free rate in the version of representative agent economy under our calibration is $13.97 \%$, because of $2.54 \%$ of the average output growth and the low intertemporal rate of substitution, $1 / \alpha$.
} 
Their investment choice deviates from the market portfolio by holding no equity and hence they do not bear any aggregate risk. In contrast to Experiments 1 and 2, replacing $70 \%$ of population from non-Mertonian equity traders to non-participants creates some residual aggregate risk. The residual risk has to be taken by other traders in equilibrium. Non-Mertonian equity traders are still assumed to hold the market portfolio and hence they are unable to absorb any extra risk. Eventually, all residual risk created by the non-participants has to be taken by Mertonian traders. There is a large amount of residual risk due to the high fraction of non-participants. Hence, the risk premium must be high in order to make a small fraction of Mertonian traders willing to take a large amount of extra risk. Eventually, Mertonian traders earn a higher average return by taking more aggregate risk and enjoy a higher level of consumption, while non-participants only earn the low risk-free return and consume less.

The last 4 rows of Panel 2 report that the wealth return and portfolio choice are identical in both countries in all experiments. In addition, the last panel reports that the US trade balance, current account, official current account, NFIA and net asset position are all zero. These zero balances clearly result from the symmetric assumption of these experiments. Most importantly, these results suggest that each country holds the market portfolio, therefore both countries bear an amount of aggregate risk exactly proportional to their country size. Since both bonds and equity are identical across countries, without loss of generality, each country holds its own assets,

consumes its own endowments and carries no international trade. Hence, all external balances become zero in all experiments. However, the results of balanced external accounts are no longer true if we assume asymmetry across countries in trading technologies and in the idiosyncratic process. In the next section, our benchmark economy considers the asymmetric case.

[Table 3 about here.]

\subsection{Benchmark Case}

Now consider the benchmark case, in which the composition of the traders pool as well as the idiosyncratic shock process in the US are different from those in the ROW.

Benchmark Calibration In order to match a high equity premium, more than $6 \%$ as measured in the post-war US data, a small fraction of Mertonian traders must absorb a large amount of 
residual risk. We therefore set the fraction of Mertonian traders to $5 \%$ for both countries. Our benchmark case does not consider the environment in which any country has a larger fraction of Mertonian traders than others. Having a larger fraction of Mertonian traders implies that the overall trading technology in one country is superior to others. However, in the sensitivity analysis in Subsection 5.5, we perform a case in which the US has a larger fraction of Mertonian traders to illustrate that our mechanism is enhanced.

Since $51 \%$ of US households do not hold stocks according to the latest Survey of Consumer Finance data, we set $50 \%$ of US investors as non-participants. We assume that the ROW on average is financially less developed than the US and hence its fraction of non-participants is higher than that of the US. In particular, we set the fraction of non-participants in the ROW to 70\% 7 , which is roughly the share of US non-participants in 1985, to reflect that the US leads other countries in terms of financial development. In addition, the high fraction of non-participants helps us match the low risk-free rate in the data. The remaining investors are non-Mertonian equity traders, and their fractions are $45 \%$ and $25 \%$ in the US and the ROW, respectively.

In our model, equity and bonds are homogeneous across countries, so our model cannot pin down the gross level of external equity and bonds of a country. We can only predict the net positions. The equity target share of non-Mertonian equity traders in the home and foreign country, together with the ROW idiosyncratic process are calibrated to match the US net foreign equity and net foreign bonds positions implied by the data. As discussed in Section 3 , the external balances statistics are reported in the last panel in Table I. The net equity position and bond position implied by the data are $50.39 \%$ and $-76.74 \%$, respectively. As a result, the equity target of the US and that of the ROW are set to $35.3 \%$ and $25 \%$. In addition, a slightly riskier idiosyncratic process of the ROW helps us match the large negative net bond position. The transition probability of the ROW idiosyncratic process remains unchanged, while the level of two states are set to $\eta_{L}=0.3510$, and $\eta_{H}=1.6490$.

Quantitative Results of Benchmark Case Similar to the symmetric economy in the previous subsection, we report the statistics of asset pricing, portfolio returns and US external balances.

\footnotetext{
${ }^{7}$ There are only limited of empirical studies on household finance outside of the US economy. Iwaisako (2009) studies the portfolio choice of Japanese households and shows that the shares of equities in household financial wealth as well as stock market participation rate have been decreasing throughout the 1990s. The Japanese stock market participation rate dropped from $30.2 \%$ in year 1990 to $25.2 \%$ in year 1999 .
} 
The benchmark asset pricing results are in the first panel of Table IV. Our benchmark economy produces a high equity premium as well as a low and stable risk-free rate. The equity premium is $6.35 \%$ and the Sharpe ratio on equity is $49 \%$. The average risk-free rate is $2.16 \%$ and its volatility is only $0.1 \%$. Hence, our calibrated model is capable of producing reasonable asset pricing results. Note that the return on bonds is less than the growth rate of output, meaning that a country can in fact run a long-run trade deficit by selling the risk-free bond abroad.

The second panel reports the wealth returns and the portfolio choices across traders and across countries. The US Mertonian traders earn an average excess return of $5.19 \%$ by holding around $81 \%$ of equity in their portfolio. Because of higher idiosyncratic risks faced by foreign investors, the ROW Mertonian traders take a slightly cautious approach. Their equity share is roughly $78 \%$ and the average excess return on wealth drops to $5.02 \%$. The US non-Mertonian equity traders realize a higher excess wealth return, $2.25 \%$, compared to the ROW non-Mertonian equity traders earning $1.59 \%$, because of the difference in equity target share, $35.3 \%$ and $25 \%$, respectively. Given that the US not only has a larger fraction of equity investors but also a higher equity target share among these investors, in aggregate, US investors have $31.21 \%$ equity share in their overall portfolio, which is higher than $21.95 \%$ among foreign investors. These equity shares include both foreign equity and domestic equity, therefore we cannot compare them to the observed equity share in US external assets and liabilities. Since the market portfolio is $25 \%$ equity and $75 \%$ bond, on average the portfolio of US investors is riskier than that of average foreign investors. As a result, the US investors are compensated by the higher overall portfolio excess return, $1.99 \%$, compared to $1.40 \%$, the overall average return of foreign investors.

The external account statistics are reported in the last panel in Table IV. The model produces $50.38 \%$ of the US net-external-equity-output ratio and $-76.16 \%$ of output in the external bond position. These statistics closely match our data in Section 3. Most importantly, the long-run average US trade balance is $-2.95 \%$ of output, suggesting the valuation effect through asset returns alone accounts for more than $50 \%$ of trade deficit in the data, $-5.52 \%$ of GDP. We also report the average trade deficit conditional on the aggregate state. The trade deficit reduces to $-2.46 \%$ during recessions and advances to $-3.13 \%$ in expansions. The behavior of the trade deficit is consistent with the recent reduction of the US trade deficit after the 2007 financial crisis. As explained in Section 3, the large trade deficit is caused by not only the high equity premium but also the low 
risk-free rate, since holding the risk-free rate is lower than the growth rate of output. In the long run, the theoretical current account becomes zero, otherwise there is no stationary equilibrium. However, the official US current account, which only considers the interest and dividend payments, is $-2.34 \%$ and the NFIA is $0.61 \%$ of output. These statistics are very close to the US data, $0.64 \%$. Clearly, ignoring capital gains creates a downward bias in the current account statistics. Finally, the US current account rises in the good state and drops in the bad state, because US traders take excess risk. The volatility of the current account is large. The conditional average during recessions and expansions are $-13.22 \%$ and $5.01 \%$ of output, respectively.

The main message of our exercise is that the net foreign asset position has no certain sign relationship with the long-run trade balance. In our model, the allocation of aggregate risk is the key determinant of the sustainability of the trade deficit. The country bearing more aggregate risk can enjoy the long-run trade deficit financed by the risk premium. As a result, the US can run a large net liability position while enjoying the trade deficit in the long run, while the ROW runs the trade surplus. In addition, our model only computes the long-run equilibrium trade deficit. If we take the increasingly worsening US external account in the past decade into consideration, then the current US trade deficit might not pose a problem at all. Consider a very simple exercise. Suppose we spread the current net external asset position, $-26.35 \%$ of GDP, into into a ten year spell, suggesting that the US consumes $2.63 \%$ of GDP more in each year. Therefore, the current large trade deficit does not necessarily imply a future increase in net exports or a dollar depreciation as predicted by the recent literature.

[Table 4 about here.]

\subsection{The Importance of the Risk Premium}

The US long-run trade deficit in our model comes from the compensation for excess aggregate risk borne by US investors. If the market price of risk is low, taking the excess risk could have a significantly small impact on the trade balance and current account. We now explore the importance of the risk premium on the trade balance in the following exercise.

Consider an economy without the aggregate risk. If there is no aggregate risk, then the return on equity is identical to the return on bonds, implying zero equity premium. The asymmetric trading technologies across countries do not matter anymore, since portfolio returns are independent of 
portfolio choices between equity and bonds. In this environment, a country with a negative external asset position in the long run must have a surplus in the trade balance unless the return on external liabilities is lower than the output growth rate. The only factor that matters to external balances here is the level of saving in each country. In this case, the precautionary saving motivated by the idiosyncratic risk plays an essential role in global imbalances. Table V clearly reflects the discussion above.

The first panel of Table $\mathrm{V}$ confirms that there is no returns differential between equity and bonds, and thus the risk premium is zero. The risk-free rate is now $3.87 \%$, which is still relatively low but higher than the growth rate of output. The results reported in the rest of Table $\mathrm{V}$ can be easily understood. Since the composition of equity and bonds in portfolios does not affect the return anymore, the wealth return statistics are identical across households and countries regardless of their trading technologies. Note that neither the portfolio choice of Mertonian traders nor the portfolio choice for each country can be determined, because now equity and bonds are the same asset. Finally, the last panel of Table Vindicates that the US net foreign asset position is negative, $-79.21 \%$ of GDP, due to the asymmetric volatility of idiosyncratic risk between the two countries. The foreign households have a stronger precautionary saving motive, because of a higher level of uncertainty in their non-diversifiable income process. They accumulate a higher level of risk-free assets compared to that of US households. More importantly, a country with a negative asset position tends to run a trade surplus in the long run, since there is no returns differential across asset categories. The US runs $1.03 \%$ of GDP of trade surplus in each period. As discussed in Section 3, a negative net asset position leads to a trade surplus in this case.

To summarize, the aggregate uncertainty as well as the level of risk premium are crucial to our results. Without the aggregate risk, the heterogeneity in trading technologies does not matter and global imbalances are driven only by the heterogeneity of idiosyncratic shocks.

[Table 5 about here.]

\subsection{Sensitivity Analyses}

We can use our model as a laboratory to examine the impact of financial deepening with respect to changing the fraction of traders in each country. We consider two cases. One varies the fraction 
of Mertonian traders and the other considers the increasing trend of stock market participation in the ROW.

Fraction of Mertonian Traders Mertonian traders are equipped with the best trading technologies. They respond to the change in investment opportunities each period by optimally adjusting their portfolios and make no investment mistakes. Increasing the fraction of Mertonian traders of a country indicates an overall progress in trading technologies.

Table VI varies the fraction of Mertonian traders in the US and/or the ROW. The first column reports the benchmark case. The second column shows the results when we increase the fraction of US Mertonian traders to $10 \%$, the third column considers the case of $10 \%$ Mertonian traders in the ROW, and finally, the last column reports the case of $10 \%$ Mertonian trader in both the US and the ROW.

The first panel of Table VI reports the lower risk premium as we increase the fraction of Mertonian traders. Given that Mertonian traders take residual risk, a larger fraction of Mertonian traders reduces the equity premium, since the aggregate risk is spread out over the larger population. The risk-free rate is slightly higher and its volatility remains almost unchanged.

As reported by the second panel of Table VI, the optimal equity share of Mertonian traders drops in all three cases because of the lower equity premium. Similar to our benchmark case, the US Mertonian traders earn a slightly higher wealth return and take more risks compared to that in the ROW, because of asymmetric idiosyncratic risks. Although the equity premium is lower compared to our benchmark case, the optimal portfolio still has a significantly higher fraction of equity than that of market portfolio. So the equity share of the portfolio of a country is positively correlated with the fraction of Mertonian traders. In the first case, the equity share of the US increases to $35.49 \%$ while the equity share of ROW drops to $19.26 \%$, simply because of the higher fraction of Mertonian traders. On the other hand, the second case reports the increase of equity share in the ROW to $23.88 \%$ and the decrease of equity share in the US to $24.62 \%$. Finally, the equity shares are relatively unchanged in the third case because of the equal percentage increment of Mertonian traders.

The last panel of Table VI demonstrates the effects on the US external account. The trade balance responds to the change of trading technologies significantly. A $5 \%$ increase in Mertonian traders pushes the net equity position into a positive number and increases the US trade deficit to 
$5.87 \%$ of US output, which is a $99 \%$ increase from the benchmark. The is because the additional Mertonian traders hold mostly equity in their portfolio. On the other hand, if the change occurs in the ROW as shown in the third column, the US trade balance improves to almost zero, $-0.09 \%$ of GDP. There is another key point worth being mentioned in the second case. Both the net external equity position and the net external bond position in the US are negative, while the trade balance is still slightly negative, meaning that the US still consumes more than its output. How is this possible? The reason is that, the return on bonds is lower than the average growth rate of output. Therefore, it is still possible that the US runs a trade deficit despite holding negative balances in all asset classes. Finally, the equal increment of Mertonian traders has a small impact on the trade balance. The US trade balance changes to $-2.21 \%$ compared to $-2.95 \%$ of GDP in the benchmark calibration. In sum, the trade balance critically depends on the overall trading technologies of a country, especially the fraction of Mertonian traders.

[Table 6 about here.]

Fraction of Non-participant Traders This subsection studies the impact of increasing stock market participation among non-Mertonian traders in the ROW. Table VII deviates the fraction of non-participants from our benchmark case to $60 \%$ and $50 \%$. In addition to the benchmark result listed in the first column, the second column reports the results of increasing the fraction of non-Mertonian equity traders to $35 \%$ and decreasing non-participants to $60 \%$. The third column further changes the fraction of non-Mertonian equity traders and non-participants to $45 \%$ and $50 \%$ respectively, while we keep other parameters unchanged.

The first panel of Table VII shows that, as we decrease the fraction of non-participants from $70 \%$ to $50 \%$, the equity premium as well as the Sharpe ratio decreases, while the risk-free rate goes up. Fewer non-participants imply less residual risk and hence the aggregate risk has been spread out over a larger pool of equity market participants. The equity premium drops slightly from $6.35 \%$ to $5.95 \%$ as the fraction of non-participants abroad changes from $70 \%$ to $50 \%$. Increasing the market participants affects the overall portfolio choice in the ROW as follows. The equity share increases from $21.95 \%$ in the benchmark case to $23.35 \%$ in the last case. This suggests that increasing market participants in the ROW shifts the load of risk from the US to the ROW.

The last panel indicates that unloading the aggregate risk of US investors impacts both the 
trade balance and the net asset position. The US trade deficit reduces from $2.95 \%$ of GDP in our benchmark, to $2.00 \%$ of GDP with $10 \%$ more market participants in the ROW and down to $1.13 \%$ of GDP as the fraction of traders becomes equalized across countries 8 The US net asset position deteriorates from the benchmark case, $-25.79 \%$ to $-52.83 \%$ in the case with $50 \%$ non-participants in the ROW.

[Table 7 about here.]

\section{Conclusion}

Our paper makes both qualitative and quantitative contributions to the literature on global imbalances. In terms of quantitative results, our calibrated model accounts for more than $50 \%$ of both the US current account deficit and the US trade deficit in the past decade, or roughly $3 \%$ of GDP. The magnitude of the trade deficit in our model could be even larger by considering the deteriorating US net asset position during the past two decades. Consequently, the large scale of the US current account deficit might not necessarily lead to net export increases or a large dollar depreciation in the future.

The qualitative prediction that the US can sustain the long-run trade deficit, or the current account deficit (excluding capital gains or losses as in the official statistics), builds on two simple conditions: (i) positive risk premium; and (ii) average US investors take a relatively larger amount of aggregate risk than average foreign investors. Therefore, we expect that any model producing these two conditions can deliver the same qualitative results. In addition, these two conditions have been supported by a large body of empirical literature. Empirical studies have shown that US investors keep loading up more risks by issuing short-term debts and investing in foreign equities. The large equity premium, as well as the low and stable risk-free rate observed in the data have been a long-standing phenomenon that many studies aim to explain.

Nevertheless, we do not claim that asymmetric trading technologies are the only cause of the large returns differential between US external assets and US external liabilities. For instance, it is possible that foreign equities are different from domestic equities because of country-specific undiversifiable risks, but we do not consider this case to emphasize the importance of composition

\footnotetext{
${ }^{8}$ Note that the equity target share of the US and the ROW are still different, $35.3 \%$ and $25 \%$ respectively.
} 
of assets. Another possible reason is provided by McGrattan and Prescott (2010), who offer intangible capital as an explanation of returns differentials in FDI.

\section{References}

Abel, A. B. (1999): "Risk Premia and Term Premia in General Equilibrium," Journal of Monetary Economics, 43, 3-33.

Alvarez, F., L. Guiso, and F. Lippi (2011): "Durable consumption and asset management with transaction and observation costs.," American Economic Review, forthcoming.

Alvarez, F., and U. Jermann (2001): "Quantitative Asset Pricing Implications of Endogenous Solvency Constraints," Review of Financial Studies, 14, 1117-1152.

Ameriks, J., And S. P. Zeldes (2004): "How do Household Portfolio Shares Vary with Age?," Working Paper Columbia University.

Angeletos, G.-M., And V. PAnousi (2011): "Financial integration, entrepreneurial risk and global dynamics," Journal of Economic Theory, 146(3), 863-896.

Bacchetta, P., And K. Benhima (2010): "The Demand for Liquid Assets, Corporate Saving, and Global Imbalances," Cahiers de Recherches Economiques du Dpartement d'Economtrie et d'Economie politique (DEEP) 10.12, Universit de Lausanne, Facult des HEC, DEEP.

Bansal, R., And A. Yaron (2004): "Risks for the Long Run: A Potential Resolution of Asset Prizing Puzzles," The Journal of Finance, 59, 1481-1509.

Brunnermeier, M. K., And S. Nagel (2008): "Do Wealth Fluctuations Generate Time-Varying Risk Aversion? Micro-Evidence on Individuals' Asset Allocation," American Economic Review, $98: 3,713-736$.

Caballero, R. J., E. Farhi, and P.-O. Gourinchas (2008): "An Equilibrium Model of Global Imbalances and Low Interest Rates," American Economic Review, 98(1), 358-93.

Calvet, L. E., J. Y. Campbell, and P. Sodini (2009): "Fight Or Flight? Portfolio Rebalancing By Individual Investors," The Quarterly Journal of Economics, February, 301-346. 
Calvo, G. A. (1998): "Capital Flows and Capital-market Crises: The Simple Economics of Sudden Stops," Journal of Applied Economics, 1, 35-54.

Calvo, G. A., A. Izquierdo, and E. Talvi (2003): "Sudden Stops, the Real Exchange Rate and Fiscal Sustainability: Argentinas Lessons," in Monetary Unions and Hard Pegs, pp. 150-181.

Campbell, J. Y., and J. H. Cochrane (1999): "By Force of Habit: A Consumption-Based Explanation of Aggregate Stock Market Behavior," Journal of Political Economy, 107(2), 205251.

Cecchetti, S. G., P. Lam, and N. C. Mark (1990): "Mean Reversion in Equilibrium Asset Prices," American Economic Review, 80(3), 398-418.

Chien, Y., H. Cole, and H. Lustig (2011): "A Multiplier Approach to Understanding the Macro Implications of Household Finance," Review of Economic Studies, 78(1), 199-234.

Curcuru, S. E., T. Dvorak, and F. E. Warnock (2008): "Cross-Border Returns Differentials," The Quarterly Journal of Economics, 123(4), 1495-1530.

(2010): "Decomposing the U.S. external returns differential," Journal of International Economics, 80(1), 22-32.

Curcuru, S. E., C. P. Thomas, F. E. Warnock, and J. Wongswan (2011): "U.S. International Equity Investment and Past and Prospective Returns," American Economic Review, 101(7), 3440-3455.

Devereux, M. B., And A. Sutherland (2010): "Valuation effects and the dynamics of net external assets," Journal of International Economics, 80(1), 129-143.

Engel, C., And J. H. Rogers (2006): "The U.S. current account deficit and the expected share of world output," Journal of Monetary Economics, 53(5), 1063-1093.

Gourinchas, P.-O., And H. Rey (2007a): "From World Banker to World Venture Capitalist: U.S. External Adjustment and the Exorbitant Privilege," in G7 Current Account Imbalances: Sustainability and Adjustment, NBER Chapters, pp. 11-66. National Bureau of Economic Research, Inc. 
(2007b): "International Financial Adjustment," Journal of Political Economy, 115(4), $665-703$.

Gourinchas, P.-O., H. Rey, and N. Govillot (2010): "Exorbitant Privilege and Exorbitant Duty," Discussion Papers 2010-E-20, Bank of Japan IMES.

Guvenen, F. (2009): "A Parsimonious Macroeconomic Model for Asset Pricing," Econometrica, $77(6), 1711-1750$.

Hnatkovska, V. (2010): "Home bias and high turnover: Dynamic portfolio choice with incomplete markets," Journal of International Economics, 80(1), 113-128.

IwAisako, T. (2009): "Household Portfolios in Japan," Japan and the World Economy, 21(4), $373-382$.

Krueger, D., And H. Lustig (2010): "When is market incompleteness irrelevant for the price of aggregate risk (and when is it not)?," Journal of Economic Theory, 145(1), 1-41.

Krusell, P., And A. J. Smith (1998): "Income and Wealth Heterogeneity in the Macroeconomy," Journal of Political Economy, 6, 867-896.

Lane, P. R., And G. M. Milesi-Ferretti (2007): “A Global Perspective on External Positions," in G7 Current Account Imbalances: Sustainability and Adjustment, NBER Chapters, pp. 67-102. National Bureau of Economic Research, Inc.

Marcet, A., And R. Marimon (1999): "Recursive Contracts," Working Paper Universitat Pompeu Fabra.

McGrattan, E. R., and E. C. Prescott (2010): "Technology Capital and the US Current Account," American Economic Review, 100(4), 1493-1522.

Mehra, R., And E. C. Prescott (1985): "The equity premium: A puzzle," Journal of Monetary Economics, 15(2), 145-161.

Meissner, C. M., And A. M. TAylor (2006): "Losing our Marbles in the New Century? The Great Rebalancing in Historical Perspective," NBER Working Papers 12580, National Bureau of Economic Research, Inc. 
Mendoza, E. G., V. Quadrini, and J.-V. Ros-Rull (2009): "Financial Integration, Financial Development, and Global Imbalances," Journal of Political Economy, 117(3), 371-416.

Neely, C. J., A. Roy, and C. H. Whiteman (2001): "Risk Aversion Versus Intertemporal Substitution: A Case Study of Identification Failure in the Intertemporal Consumption Capital Asset Pricing Model," Journal of Business and Economic Statistics, 19(4), 395-403.

Obstfeld, M., and K. Rogoff (2000): "Perspectives on OECD economic integration : implications for U.S. current account adjustment," in Global Economic Integration: Opportunities and Challenges, pp. 169-208. Federal Reserve Bank of Kansas City.

— (2007): "The Unsustainable U.S. Current Account Position Revisited," in Gr Current Account Imbalances: Sustainability and Adjustment, NBER Chapters, pp. 339-376. National Bureau of Economic Research, Inc.

Obstfeld, M., and K. S. Rogoff (2005): "Global Current Account Imbalances and Exchange Rate Adjustments," Brookings Papers on Economic Activity, 36(1), 67-146.

Storesletten, K., C. Telmer, And A. Yaron (2004): "Cyclical Dynamics of Idiosyncratic Labor Market Risk," The Journal of Political Economy.

(2007): "Asset Pricing with Idiosyncratic Risk and Overlapping Generations," Review of Economic Dynamics, 10(4), 519-548.

Tille, C., And E. VAN Wincoop (2010): "International capital flows," Journal of International Economics, 80(2), 157-175. 
Table I: Average of US External Balances Relative to Output, 2000-2009 (\%)

\begin{tabular}{lc}
\hline \hline Description & Average \\
\hline & \\
A. International Investment Position & \\
& \\
External asset position/output & 107.11 \\
External liability position/output & 133.46 \\
Net external asset position/output & -26.35 \\
Net external equity position/output & 50.39 \\
Net external bond position/output & -76.74 \\
& \\
B. Balance of Payments & \\
\hline & \\
Current account/output & -4.88 \\
Trade balance/output & -5.52 \\
Net factor income account/output & 0.64 \\
\hline \hline
\end{tabular}

Source: US Bureau of Economic Analysis

Notes: Net external equity position/output and net external bond position/output are Authors' calculation to replicate the average portfolio returns in Gourinchas and Rey (2007a). 


\section{Table II: Common Parameter Values for All Cases}

\begin{tabular}{|c|c|c|c|}
\hline Parameter & Description & \multicolumn{2}{|c|}{ Value } \\
\hline & \multicolumn{3}{|l|}{ A. Structural Parameter } \\
\hline$\delta^{U S}$ & US share of world GDP & \multicolumn{2}{|c|}{0.33} \\
\hline$\delta^{R O W}$ & ROW share of world GDP & \multicolumn{2}{|c|}{0.67} \\
\hline$\beta$ & Annual discount factor & \multicolumn{2}{|c|}{1.00} \\
\hline$\gamma$ & Degree of risk aversion & \multicolumn{2}{|c|}{6.00} \\
\hline$\phi^{i}, i=U S, R O W$ & Leverage ratio & \multicolumn{2}{|c|}{3.00} \\
\hline$\gamma^{i}, i=U S, R O W$ & Share of non-diversifiable output & \multicolumn{2}{|c|}{0.90} \\
\hline & B. Aggregate Shock Process & & \\
\hline \multirow{2}{*}{$\pi\left(z^{\prime} \mid z\right)$} & \multirow{2}{*}{ Transition probability } & 0.2740 & 0.7260 \\
\hline & & 0.2740 & 0.7260 \\
\hline$z_{L}$ & Consumption growth in a recession & \multicolumn{2}{|c|}{0.9762} \\
\hline$z_{H}$ & Consumption growth in an expansion & \multicolumn{2}{|c|}{1.0440} \\
\hline$\sigma\left(z_{t}\right)$ & Standard deviation of consumption growth & \multicolumn{2}{|c|}{0.0302} \\
\hline \multirow[t]{2}{*}{$\rho\left(z_{t}, z_{t-1}\right)$} & 1st order auto-correlation of consumption growth & \multicolumn{2}{|c|}{0} \\
\hline & C. US Idiosyncratic Shock Process & & \\
\hline \multirow{2}{*}{$\pi\left(\eta^{\prime} \mid \eta\right)$} & \multirow{2}{*}{ Transition probability } & 0.9450 & 0.0550 \\
\hline & & 0.0550 & 0.9450 \\
\hline$\eta_{L}$ & Labor income shock in a recession & \multicolumn{2}{|c|}{0.3894} \\
\hline$\eta_{H}$ & Labor income shock in an expansion & \multicolumn{2}{|c|}{1.6106} \\
\hline$\sigma\left(\eta_{t}\right)$ & Standard deviation of labor income & \multicolumn{2}{|c|}{0.71} \\
\hline$\rho\left(\eta_{t}, \eta_{t-1}\right)$ & 1st order auto-correlation of labor income & \multicolumn{2}{|c|}{0.89} \\
\hline
\end{tabular}




\section{Table III: Three Experiments in Symmetric Case}

\begin{tabular}{|c|c|c|c|}
\hline & Experiment 1 & Experiment 2 & Experiment 3 \\
\hline Mertonian & $100 \%$ & $5 \%$ & $5 \%$ \\
\hline Non-Mertonian Equity & $0 \%$ & $95 \%$ & $25 \%$ \\
\hline \multirow{2}{*}{ Non-Participant } & $0 \%$ & $0 \%$ & $70 \%$ \\
\hline & \multicolumn{3}{|c|}{ Panel I: Asset Pricing Result (\%) } \\
\hline$E\left(R_{D}-R_{f}\right)$ & 2.38 & 2.38 & 6.69 \\
\hline$\sigma\left(R_{D}-R_{f}\right)$ & 12.27 & 12.27 & 13.24 \\
\hline$\frac{E\left(R_{D}-R_{f}\right)}{\sigma\left(R_{D}-R_{f}\right)}$ & 19.41 & 19.41 & 50.52 \\
\hline$E\left(R_{f}\right)$ & 3.26 & 3.26 & 2.13 \\
\hline \multirow[t]{2}{*}{$\sigma\left(R_{f}\right)$} & 0.00 & 0.00 & 0.11 \\
\hline & \multicolumn{3}{|c|}{ Panel II: Portfolio and Return (\%) } \\
\hline$E\left(R_{W}-R_{f}\right)_{M}$ & 0.60 & 0.60 & 5.33 \\
\hline$E\left(R_{W}-R_{f}\right)_{E T}$ & $N A$ & 0.60 & 1.67 \\
\hline$E\left(R_{W}-R_{f}\right)_{U S}$ & 0.60 & 0.60 & 1.67 \\
\hline$E\left(R_{W}-R_{f}\right)_{R O W}$ & 0.60 & 0.60 & 1.67 \\
\hline$E(\omega)_{M}$ & 25.00 & 25.00 & 79.07 \\
\hline$E(\omega)_{E T}$ & $N A$ & 25.00 & 25.00 \\
\hline$E(\omega)_{U S}$ & 25.00 & 25.00 & 25.00 \\
\hline \multirow[t]{2}{*}{$E(\omega)_{R O W}$} & 25.00 & 25.00 & 25.00 \\
\hline & \multicolumn{3}{|c|}{ Panel III: External Balance (\%) } \\
\hline$E\left(\frac{T B}{Y}\right)_{U S}$ & 0 & 0 & 0 \\
\hline$E\left(\frac{C A}{Y}\right)_{U S}$ & 0 & 0 & 0 \\
\hline$E\left(\frac{C A^{o}}{Y}\right)_{U S}$ & 0 & 0 & 0 \\
\hline$E\left(\frac{N F I A}{Y}\right)_{U S}$ & 0 & 0 & 0 \\
\hline$E\left(\frac{N e t E q u i t y}{Y}\right)_{U S}$ & 0 & 0 & 0 \\
\hline$E\left(\frac{\text { NetBond }}{Y}\right)_{U S}$ & 0 & 0 & 0 \\
\hline$E\left(\frac{N e t A s s e t}{Y}\right)_{U S}$ & 0 & 0 & 0 \\
\hline
\end{tabular}

Notes: Parameters setting: $\gamma=6, \beta=1$, diversified share of income is 0.1 . The simulation results are generated by an economy with 18,000 agents and 10,000 periods. 
Table IV: The Results of Benchmark Calibration

\begin{tabular}{|c|c|}
\hline & Share of Traders (\%) \\
\hline & Benchmark \\
\hline US Mertonian & 5.00 \\
\hline US Non-Mertonian Equity & 45.00 \\
\hline US Non-Participant & 50.00 \\
\hline ROW Mertonian & 5.00 \\
\hline ROW Non-Mertonian Equity & 25.00 \\
\hline \multirow[t]{2}{*}{ ROW Non-Participant } & 70.00 \\
\hline & Panel I: Asset Pricing Result (\%) \\
\hline$E\left(R_{D}-R_{f}\right)$ & 6.35 \\
\hline$\sigma\left(R_{D}-R_{f}\right)$ & 12.99 \\
\hline$\frac{E\left(R_{D}-R_{f}\right)}{\sigma\left(R_{D}-R_{f}\right)}$ & 48.93 \\
\hline$E\left(R_{f}\right)$ & 2.16 \\
\hline \multirow[t]{2}{*}{$\sigma\left(R_{f}\right)$} & 0.10 \\
\hline & Panel II: Portfolio and Return (\%) \\
\hline$E\left(R_{W}-R_{f}\right)_{M, U S}$ & 5.19 \\
\hline$E\left(R_{W}-R_{f}\right)_{M, R O W}$ & 5.02 \\
\hline$E\left(R_{W}-R_{f}\right)_{E T, U S}$ & 2.25 \\
\hline$E\left(R_{W}-R_{f}\right)_{E T, R O W}$ & 1.59 \\
\hline$E\left(R_{W}-R_{f}\right)_{U S}$ & 1.99 \\
\hline$E\left(R_{W}-R_{f}\right)_{R O W}$ & 1.40 \\
\hline$E(\omega)_{M, U S}$ & 80.78 \\
\hline$E(\omega)_{M, R O W}$ & 78.28 \\
\hline$E(\omega)_{E T, U S}$ & 35.30 \\
\hline$E(\omega)_{E T, R O W}$ & 25.00 \\
\hline$E(\omega)_{U S}$ & 31.21 \\
\hline \multirow[t]{2}{*}{$E(\omega)_{R O W}$} & 21.95 \\
\hline & Panel III: US External Balance (\%) \\
\hline$E\left(\frac{T B}{Y}\right)_{U S}$ & -2.95 \\
\hline$E\left(\frac{T B}{Y} \mid z=R\right)_{U S}$ & -2.46 \\
\hline$E\left(\frac{T B}{Y} \mid z=E\right)_{U S}$ & -3.13 \\
\hline$E\left(\frac{C A}{Y}\right)_{U S}$ & 0 \\
\hline$E\left(\frac{C A}{Y} \mid z=R\right)_{U S}$ & -13.22 \\
\hline$E\left(\frac{C A}{Y} \mid z=E\right)_{U S}$ & 5.01 \\
\hline$E\left(\frac{C A^{o}}{Y}\right)_{U S}$ & -2.34 \\
\hline$E\left(\frac{N F I A}{Y}\right)_{U S}$ & 0.61 \\
\hline$E\left(\frac{N e t E q u i t y}{Y}\right)_{U S}$ & 50.38 \\
\hline$E\left(\frac{\text { NetBond }}{Y}\right)_{U S}$ & -76.16 \\
\hline$E\left(\frac{\text { NetAsset }}{Y}\right)_{U S}$ & -25.79 \\
\hline
\end{tabular}

Notes: The simulation results are generated by an economy with 18, 000 agents for each type and 10,000 periods. 
Table V: The Results without Aggregate Shocks

\begin{tabular}{|c|c|}
\hline & Share of Traders (\%) \\
\hline US Mertonian & 5.00 \\
\hline US Non-Mertonian Equity & 45.00 \\
\hline US Non-Participant & 50.00 \\
\hline ROW Mertonian & 5.00 \\
\hline ROW Non-Mertonian Equity & 25.00 \\
\hline \multirow[t]{2}{*}{ ROW Non-Participant } & 70.00 \\
\hline & Panel I: Asset Pricing Result (\%) \\
\hline$E\left(R_{D}-R_{f}\right)$ & 0 \\
\hline$\sigma\left(R_{D}-R_{f}\right)$ & 0 \\
\hline$\frac{E\left(R_{D}-R_{f}\right)}{\sigma\left(R_{D}-R_{f}\right)}$ & $N A$ \\
\hline$E\left(R_{f}\right)$ & 3.87 \\
\hline \multirow[t]{2}{*}{$\sigma\left(R_{f}\right)$} & 0 \\
\hline & Panel II: Portfolio and Return (\%) \\
\hline$E\left(R_{W}-R_{f}\right)_{M, U S}$ & 0 \\
\hline$E\left(R_{W}-R_{f}\right)_{M, R O W}$ & 0 \\
\hline$E\left(R_{W}-R_{f}\right)_{E T, U S}$ & 0 \\
\hline$E\left(R_{W}-R_{f}\right)_{E T, R O W}$ & 0 \\
\hline$E\left(R_{W}-R_{f}\right)_{U S}$ & 0 \\
\hline$E\left(R_{W}-R_{f}\right)_{R O W}$ & 0 \\
\hline$E(\omega)_{E T, U S}$ & 35.30 \\
\hline \multirow[t]{2}{*}{$E(\omega)_{E T, R O W}$} & 25.00 \\
\hline & Panel III: External Balance (\%) \\
\hline$E\left(\frac{T B}{Y}\right)_{U S}$ & 1.03 \\
\hline$E\left(\frac{C A}{Y}\right)_{U S}$ & 0 \\
\hline$E\left(\frac{N e t A s s e t}{Y}\right)_{U S}$ & -79.21 \\
\hline
\end{tabular}

Notes: The simulation results are generated by an economy with 18,000 agents for each type and 10,000 periods. 
Table VI: Effects of Size of Mertonian Traders

\begin{tabular}{|c|c|c|c|c|}
\hline & \multicolumn{4}{|c|}{ Share of Traders (\%) } \\
\hline & Benchmark & Case 1 & Case 2 & Case 3 \\
\hline US Mertonian & 5.00 & 10.00 & 5.00 & 10.00 \\
\hline US Non-Mertonian Equity & 45.00 & 40.00 & 45.00 & 40.00 \\
\hline US Non-Participant & 50.00 & 50.00 & 50.00 & 50.00 \\
\hline ROW Mertonian & 5.00 & 5.00 & 10.00 & 10.00 \\
\hline ROW Non-Mertonian Equity & 25.00 & 25.00 & 20.00 & 20.00 \\
\hline \multirow[t]{2}{*}{ ROW Non-Participant } & 70.00 & 70.00 & 70.00 & 70.00 \\
\hline & \multicolumn{4}{|c|}{ Panel I: Asset Pricing Result (\%) } \\
\hline$E\left(R_{D}-R_{f}\right)$ & 6.35 & 6.04 & 5.69 & 5.47 \\
\hline$\sigma\left(R_{D}-R_{f}\right)$ & 12.99 & 12.91 & 12.82 & 12.76 \\
\hline$\frac{E\left(R_{D}-R_{f}\right)}{\sigma\left(R_{D}-R_{f}\right)}$ & 48.93 & 46.79 & 44.42 & 42.87 \\
\hline$E\left(R_{f}\right)$ & 2.16 & 2.24 & 2.32 & 2.38 \\
\hline \multirow[t]{2}{*}{$\sigma\left(R_{f}\right)$} & 0.10 & 0.09 & 0.08 & 0.08 \\
\hline & \multicolumn{4}{|c|}{ Panel II: Portfolio and Return (\%) } \\
\hline$E\left(R_{W}-R_{f}\right)_{M, U S}$ & 5.19 & 4.87 & 4.48 & 4.21 \\
\hline$E\left(R_{W}-R_{f}\right)_{M, R O W}$ & 5.02 & 4.69 & 4.30 & 4.04 \\
\hline$E\left(R_{W}-R_{f}\right)_{E T, U S}$ & 2.25 & 2.14 & 2.01 & 1.93 \\
\hline$E\left(R_{W}-R_{f}\right)_{E T, R O W}$ & 1.59 & 1.51 & 1.43 & 1.37 \\
\hline$E\left(R_{W}-R_{f}\right)_{U S}$ & 1.99 & 2.15 & 1.55 & 1.70 \\
\hline$E\left(R_{W}-R_{f}\right)_{R O W}$ & 1.40 & 1.17 & 1.36 & 1.21 \\
\hline$E(\omega)_{M, U S}$ & 80.78 & 79.76 & 77.95 & 76.31 \\
\hline$E(\omega)_{M, R O W}$ & 78.28 & 76.96 & 74.92 & 73.21 \\
\hline$E(\omega)_{E T, U S}$ & 35.30 & 35.30 & 35.30 & 35.30 \\
\hline$E(\omega)_{E T, R O W}$ & 25.00 & 25.00 & 25.00 & 25.00 \\
\hline$E(\omega)_{U S}$ & 31.21 & 35.49 & 27.10 & 30.98 \\
\hline \multirow[t]{2}{*}{$E(\omega)_{R O W}$} & 21.95 & 19.26 & 23.88 & 22.03 \\
\hline & \multicolumn{4}{|c|}{ Panel III: External Balance (\%) } \\
\hline$E\left(\frac{T B}{Y}\right)_{U S}$ & -2.95 & -5.87 & -0.09 & -2.21 \\
\hline$E\left(\frac{C A}{Y}\right)_{U S}$ & 0 & 0 & 0 & 0 \\
\hline$E\left(\frac{C A^{o}}{Y}\right)_{U S}$ & -2.34 & -2.77 & -1.98 & -2.35 \\
\hline$E\left(\frac{N F I A}{Y}\right)_{U S}$ & 0.61 & 3.10 & -1.89 & -0.15 \\
\hline$E\left(\frac{\text { NetEquity }}{Y}\right)_{U S}$ & 50.38 & 111.59 & -1.28 & 44.84 \\
\hline$E\left(\frac{\text { NetBond }}{Y}\right)_{U S}$ & -76.16 & -75.94 & -79.00 & -81.18 \\
\hline$E\left(\frac{\text { NetAsset }}{Y}\right)_{U S}$ & -25.79 & 35.65 & -80.28 & -36.34 \\
\hline
\end{tabular}

Notes: The simulation results are generated by an economy with 18,000 agents for each type and 10,000 periods. 
Table VII: Effects of Equity Market Participation

\begin{tabular}{|c|c|c|c|}
\hline & \multicolumn{3}{|c|}{ Share of Traders (\%) } \\
\hline & Benchmark & Case 1 & Case 2 \\
\hline US Mertonian & 5.00 & 5.00 & 5.00 \\
\hline US Non-Mertonian Equity & 45.00 & 45.00 & 45.00 \\
\hline US Non-Participant & 50.00 & 50.00 & 50.00 \\
\hline ROW Mertonian & 5.00 & 5.00 & 5.00 \\
\hline ROW Non-Mertonian Equity & 25.00 & 35.00 & 45.00 \\
\hline \multirow[t]{2}{*}{ ROW Non-Participant } & 70.00 & 60.00 & 50.00 \\
\hline & \multicolumn{3}{|c|}{ Panel I: Asset Pricing Result (\%) } \\
\hline$E\left(R_{D}-R_{f}\right)$ & 6.35 & 6.11 & 5.95 \\
\hline$\sigma\left(R_{D}-R_{f}\right)$ & 12.99 & 12.79 & 12.75 \\
\hline$\frac{E\left(R_{D}-R_{f}\right)}{\sigma\left(R_{D}-R_{f}\right)}$ & 48.93 & 47.77 & 46.63 \\
\hline$E\left(R_{f}\right)$ & 2.16 & 2.22 & 2.26 \\
\hline \multirow[t]{2}{*}{$\sigma\left(R_{f}\right)$} & 0.10 & 0.09 & 0.09 \\
\hline & \multicolumn{3}{|c|}{ Panel II: Portfolio and Return (\%) } \\
\hline$E\left(R_{W}-R_{f}\right)_{M, U S}$ & 5.19 & 4.97 & 4.83 \\
\hline$E\left(R_{W}-R_{f}\right)_{M, R O W}$ & 5.02 & 4.80 & 4.66 \\
\hline$E\left(R_{W}-R_{f}\right)_{E T, U S}$ & 2.25 & 2.16 & 2.10 \\
\hline$E\left(R_{W}-R_{f}\right)_{E T, R O W}$ & 1.59 & 1.53 & 1.49 \\
\hline$E\left(R_{W}-R_{f}\right)_{U S}$ & 1.99 & 1.83 & 1.72 \\
\hline$E\left(R_{W}-R_{f}\right)_{R O W}$ & 1.40 & 1.38 & 1.39 \\
\hline$E(\omega)_{M, U S}$ & 80.78 & 80.60 & 80.37 \\
\hline$E(\omega)_{M, R O W}$ & 78.28 & 77.90 & 77.52 \\
\hline$E(\omega)_{E T, U S}$ & 35.30 & 35.30 & 35.30 \\
\hline$E(\omega)_{E T, R O W}$ & 25.00 & 25.00 & 25.00 \\
\hline$E(\omega)_{U S}$ & 31.21 & 29.96 & 28.94 \\
\hline \multirow[t]{2}{*}{$E(\omega)_{R O W}$} & 21.95 & 22.49 & 23.35 \\
\hline & \multicolumn{3}{|c|}{ Panel III: External Balance (\%) } \\
\hline$E\left(\frac{T B}{Y}\right)_{U S}$ & -2.95 & -2.00 & -1.13 \\
\hline$E\left(\frac{C A}{Y}\right)_{U S}$ & 0 & 0 & 0 \\
\hline$E\left(\frac{C A^{o}}{Y}\right)_{U S}$ & -2.34 & -2.13 & -1.92 \\
\hline$E\left(\frac{N F I A}{Y}\right)_{U S}$ & 0.61 & -0.13 & -0.79 \\
\hline$E\left(\frac{\text { NetEquity }}{Y}\right)_{U S}$ & 50.38 & 35.26 & 19.95 \\
\hline$E\left(\frac{N e t B o n d}{Y}\right)_{U S}$ & -76.16 & -75.03 & -72.78 \\
\hline$E\left(\frac{N e t A s s e t}{Y}\right)_{U S}$ & -25.79 & -39.77 & -52.83 \\
\hline
\end{tabular}

Notes: The simulation results are generated by an economy with 18,000 agents for each type and 10,000 periods. 


\section{A Computation of the US External Position}

Our data series are from the US Bureau of Economic Analysis (BEA). The private consumption and government consumption series are from the BEA's National Income Product Account. The balance of payments statistics are from the BEA's US International Transactions. The external position series are from the BEA's International Investment Position of the United States at Year End.

As in Gourinchas and Rey (2007a), we exclude financial derivatives from both the asset position and the liability position, because the data of financial derivatives before 2004 are not available. The difference in our statistics and their statistics is in the treatment of US government holdings of gold, special drawing rights and reserve position in the International Monetary Fund. Gourinchas and Rey (2007a) include them in the US external asset position, but we exclude them for the following reasons. One, changes in the value of US government holdings of gold, special drawing rights and reserve position in the International Monetary Fund are not driven by portfolio adjustments and merely reflect the valuation of assets. Two, holdings of long-term assets by US government are not driven by a portfolio choice, since these assets include paid-in capital subscriptions to international financial institutions and resources provided to foreigners under foreign assistance programs requiring repayment over several years. To be precise, we calculate the US external asset position and the US external liability position as follows.

1. US external asset position $\left(A_{t}\right)=$ Foreign direct investment at current cost + Foreign corporate stock securities + US official holding of foreign currencies + US private holding of

foreign bond securities + US claims on unaffiliated foreigners reported by US nonbanking concerns + US claims reported by US banks and securities brokers, not included elsewhere.

2. US external liability position $\left(L_{t}\right)=$ Foreign-owned direct investment at current cost + Foreign-owned US corporate stock securities + Foreign holding of US Treasury securities + Foreign holding of US securities other than Treasury securities + Foreign holding of US corporate and other bond securities + Foreign holding of US currency + US official liabilities reported by US banks and securities brokers, not included elsewhere + Other foreign official assets + US liabilities to unaffiliated foreigners reported by US nonbanking concerns + US liabilities reported by US banks and securities brokers, not included elsewhere 


\section{B Details on Household Problem}

\section{B.1 Measurability Restrictions}

To capture these portfolio restrictions implied by the different trading technologies, we use measureability constraints (see Chien, Cole, and Lustig (2011) for a detailed discussion) on net wealth. These restrictions allow us to solve for equilibrium allocations and prices without searching for all the equilibrium prices that clear each security market.

Mertonian Traders Since Mertonian traders are able to trade state-contingent claims, their asset holding can depend on the aggregate state but not the idiosyncratic state. The net wealth of Mertonian trader at country $i$ needs to satisfy:

$$
a_{t}^{i}\left(z^{t},\left[\eta_{i, t}, \eta^{i, t-1}\right]\right)=a_{t}^{i}\left(z^{t},\left[\tilde{\eta}_{i, t}, \eta^{i, t-1}\right]\right),
$$

for all $t$ and $\eta_{i, t}, \tilde{\eta}_{i, t} \in N$.

Non-Mertonian Traders Equity target traders who hold a fixed fraction $\omega^{*}$ in levered equity and $1-\omega^{*}$ in non-contingent bonds in their portfolio earn a portfolio return:

$$
R_{t}^{p}\left(\omega^{*}, z^{t}\right)=\omega^{*} R_{t, t-1}^{d}\left(z^{t}\right)+\left(1-\omega^{*}\right) R_{t, t-1}^{f}\left(z^{t-1}\right)
$$

where $R_{t, t-1}^{d}\left(z^{t}\right)$ denotes for the equity return between period $t$ and $t-1$ given the realization of history state $z^{t}$. Hence, their net financial wealth satisfies this measurability restriction:

$$
\frac{a_{t}^{i}\left(\left[z_{t}, z^{t-1}\right],\left[\eta_{t}, \eta^{t-1}\right]\right)}{R_{t}^{p}\left(\omega^{*},\left[z_{t}, z^{t-1}\right]\right)}=\frac{a_{t}\left(\left[\tilde{z}_{t}, z^{t-1}\right],\left[\tilde{\eta}_{t}, \eta^{t-1}\right]\right)}{R_{t}^{p}\left(\omega^{*},\left[\tilde{z}_{t}, z^{t-1}\right]\right)}
$$

for all $t, z_{t}, \tilde{z}_{t} \in Z$, and $\eta_{t}, \tilde{\eta}_{t} \in N$. If $\omega^{*}=1 /(1+\psi)$, then this trader holds the market in each period and earns the return on a claim to aggregate diversifiable output. There is a special type of passive traders who do not participate in the equity market and only holds risk free assets. We call them non-participants, who can be thought of as those passive traders with zero equity target share, $\omega^{*}=0$. 


\section{B.2 Saddle Point Problem}

It is convenient to write household problems in the fashion of zero trading. From the aggregate state-contingent prices on consumption, we can back out the time zero price of a consumption claim on state $z^{t}$

$$
P\left(z^{t}\right) \pi\left(z^{t}\right)=Q\left(z_{t}, z^{t-1}\right) Q\left(z_{t-1}, z^{t-2}\right) \cdots Q\left(z_{1}, z^{0}\right) Q\left(z_{0}\right)
$$

Mertonian traders Let's start with the Mertonian trader's problem in country $i$. Let $\chi$ denote the multiplier on the present-value budget constraint, let $\nu\left(z^{t}, \eta^{i, t}\right)$ denote the multiplier on the measurability constraint in node $\left(z^{t}, \eta^{i, t}\right)$, and, finally, let $\varphi\left(z^{t}, \eta^{i, t}\right)$ denote the multiplier on the debt constraint. The saddle point problem of a Mertonian in country $i$ can be stated as:

$$
\begin{aligned}
L= & \min _{\{\chi, \nu, \varphi\}} \max _{\{c, a\}} \sum_{t=1}^{\infty} \beta^{t} \sum_{\left(z^{t}, \eta^{i, t}\right)} u\left(c_{t}^{i}\left(z^{t}, \eta^{i, t}\right)\right) \pi\left(z^{t}, \eta^{i, t}\right) \\
& +\chi\left\{\sum_{t=1}^{\infty} \sum_{\left(z^{t}, \eta^{i, t}\right)} \widetilde{P}\left(z^{t}, \eta^{t}\right)\left[\gamma^{i} Y_{t}^{i}\left(z^{t}\right) \eta_{t}^{i}-c_{t}^{i}\left(z^{t}, \eta^{i, t}\right)\right]+\omega\left(z^{0}\right)\right\} \\
& +\sum_{t=1}^{\infty} \sum_{\left(z^{t}, \eta^{i, t}\right)} \nu_{t}^{i}\left(z^{t}, \eta^{i, t}\right)\left\{\begin{array}{c}
\sum_{\tau \geq t} \sum_{\left(z^{\tau}, \eta^{\tau}\right) \succeq\left(z^{t}, \eta^{t}\right)} \widetilde{P}\left(z^{\tau}, \eta^{\tau}\right)\left[\gamma^{i} Y_{\tau}^{i}\left(z^{t}\right) \eta_{\tau}^{i}-c_{\tau}^{i}\left(z^{\tau}, \eta^{\tau}\right)\right] \\
+\widetilde{P}\left(z^{t}, \eta^{t}\right) a_{t}\left(z^{t}, \eta^{i, t-1}\right)
\end{array}\right\} \\
& +\sum_{t=1}^{\infty} \sum_{\left(z^{t}, \eta^{i, t}\right)} \varphi_{t}^{i}\left(z^{t}, \eta^{i, t}\right)\left\{\begin{array}{c}
M_{t}\left(z^{t}, \eta^{t}\right) \widetilde{P}\left(z^{t}, \eta^{i, t}\right)- \\
\sum_{\tau \geq t} \sum_{\left(z^{\tau}, \eta^{\tau}\right) \succeq\left(z^{t}, \eta^{t}\right)} \widetilde{P}\left(z^{\tau}, \eta^{\tau}\right)\left[\gamma^{i} Y^{i}\left(z^{\tau}\right) \eta_{\tau}^{i}-c_{\tau}^{i}\left(z^{\tau}, \eta^{i, \tau}\right)\right]
\end{array}\right\},
\end{aligned}
$$

where $\widetilde{P}\left(z^{t}, \eta^{i, t}\right)=\pi\left(z^{t}, \eta^{i, t}\right) P\left(z^{t}\right)$.

The first order condition with respect to consumption is given by

$$
\beta^{t} u^{\prime}\left(c_{t}^{i}\left(s^{t}, \eta^{i, t}\right)\right)=\zeta\left(z^{t}, \eta^{i, t}\right) P\left(z^{t}\right) \text { for all } z^{t}, \eta^{i, t}
$$

where $\zeta\left(z^{t}, \eta^{i, t}\right)$ is defined recursively as

$$
\zeta\left(z^{t}, \eta^{i, t}\right)=\zeta\left(z^{t-1}, \eta^{i, t-1}\right)+\nu\left(z^{t}, \eta^{i, t}\right)-\varphi\left(z^{t}, \eta^{i, t}\right)
$$

with initial $\zeta_{0}=\chi$. (See Marcet and Marimon (1999) for this recursive method). 
The first-order condition with respect to total asset holding:

$$
\sum_{\eta^{i, t}} \nu_{t}^{i}\left(z^{t}, \eta^{i, t}\right) \pi\left(\eta^{i, t}\right)=0 \text { for all } z^{t}, \eta^{i, t}
$$

It is easy to show that this is a standard convex programming problem, so the first order conditions are necessary and sufficient.

Non-Mertonian Traders The saddle point problem of an equity target trader with target share $\omega$ in country $i$ can be stated as:

$$
\begin{aligned}
L= & \min _{\{\chi, \nu, \varphi\}} \max _{\left\{c^{i}, a e^{i}\right\}} \sum_{t=1}^{\infty} \beta^{t} \sum_{\left(z^{t}, \eta^{i, t}\right)} u\left(c_{t}^{i}\left(z^{t}, \eta^{i, t}\right)\right) \pi\left(z^{t}, \eta^{i, t}\right) \\
& +\chi\left\{\sum_{t=1}^{\infty} \sum_{\left(z^{t}, \eta^{i, t}\right)} \widetilde{P}\left(z^{t}, \eta^{t}\right)\left[\gamma^{i} Y_{t}^{i}\left(z^{t}\right) \eta_{t}^{i}-c_{t}^{i}\left(z^{t}, \eta^{i, t}\right)\right]+\omega\left(z^{0}\right)\right\} \\
& +\sum_{t=1}^{\infty} \sum_{\left(z^{t}, \eta^{i, t}\right)} \nu_{t}^{i}\left(z^{t}, \eta^{i, t}\right)\left\{\begin{array}{c}
\sum_{\tau \geq t} \sum_{\left(z^{\tau}, \eta^{\tau}\right) \succeq\left(z^{t}, \eta^{t}\right)} \widetilde{P}\left(z^{\tau}, \eta^{\tau}\right)\left[\gamma^{i} Y_{\tau}^{i}\left(z^{t}\right) \eta_{\tau}^{i}-c_{\tau}^{i}\left(z^{\tau}, \eta^{\tau}\right)\right] \\
+\widetilde{P}\left(z^{t}, \eta^{t}\right) R_{t, t-1}^{p, \omega}\left(z^{t}\right) a e_{t-1}^{i}\left(z^{t-1}, \eta^{i, t-1}\right)
\end{array}\right\} \\
& +\sum_{t=1}^{\infty} \sum_{\left(z^{t}, \eta^{i, t}\right)} \varphi_{t}^{i}\left(z^{t}, \eta^{i, t}\right)\left\{\begin{array}{c}
-M_{t}\left(z^{t}, \eta^{t}\right) \widetilde{P}\left(z^{t}, \eta^{i, t}\right)- \\
\sum_{\tau \geq t} \sum_{\left(z^{\tau}, \eta^{\tau}\right) \succeq\left(z^{t}, \eta^{t}\right)} \widetilde{P}\left(z^{\tau}, \eta^{\tau}\right)\left[\gamma^{i} Y^{i}\left(z^{\tau}\right) \eta_{\tau}^{i}-c_{\tau}^{i}\left(z^{\tau}, \eta^{i, \tau}\right)\right]
\end{array}\right\},
\end{aligned}
$$

where

$$
R_{t+1, t}^{p, \omega}\left(z^{t}\right)=\sum_{i} \omega^{i} R_{t, t-1}^{i, d}\left(z^{t}\right)+\left(1-\sum_{i} \omega^{i}\right) R_{t, t-1}^{f}\left(z^{t-1}\right) .
$$

The first order condition with respect to consumption is given by

$$
\beta^{t} u^{\prime}\left(c_{t}^{i}\left(s^{t}, \eta^{i, t}\right)\right)=\zeta\left(z^{t}, \eta^{i, t}\right) P\left(z^{t}\right) \text { for all } z^{t}, \eta^{i, t},
$$

where $\zeta\left(z^{t}, \eta^{i, t}\right)$ is defined as in Equation (17). The first order condition respect to consumption is independent of trading technologies. The first order condition with respect to total asset holding in the end of period $t-1, a e_{t-1}^{i}\left(z^{t-1}, \eta^{i, t-1}\right)$

$$
\sum_{\left(z^{t}, \eta^{i, t}\right)} R_{t+1, t}^{p, \omega}\left(z^{t}\right) \nu_{t}^{i}\left(z^{t}, \eta^{i, t}\right) P\left(z^{t}\right) \pi\left(z^{t,} \eta^{i t}\right)=0 \text { for all } z^{t}, \eta^{i, t}
$$


We refer to this as the martingale condition. This condition is specific to the trading technology.

\section{B.3 Stochastic Discount Factor}

Starting from the common first-order condition for consumption

$$
c_{t}^{i}\left(z^{t}, \eta^{i, t}\right)=u^{\prime-1}\left[\frac{\zeta^{i, t}\left(z^{t}, \eta^{i, t}\right) P\left(z^{t}\right)}{\beta^{t}}\right] .
$$

In addition, the sum of individual consumption aggregate up to aggregate consumption at country $i$ :

$$
C_{t}^{i}\left(z^{t}\right)=\mu^{i} \sum_{\eta^{i, t}} c_{t}^{i}\left(z^{t}, \eta^{i, t}\right) \pi\left(\eta^{i, t}\right)
$$

and aggregate consumption world wide

$$
\sum_{i=1}^{I} C_{t}^{i}\left(z^{t}\right)=C_{t}\left(z^{t}\right)
$$

With CRRA preferences, this implies that the household consumption share relative to aggregate consumption with history $\left(z^{t}, \eta^{i, t}\right)$ is given by

$$
\frac{c_{t}^{i}\left(z^{t}, \eta^{i, t}\right)}{C_{t}\left(z^{t}\right)}=\frac{\zeta^{i}\left(z^{t}, \eta^{i, t}\right)^{\frac{-1}{\alpha}}}{h\left(z^{t}\right)}
$$

where

$$
h_{t}\left(z^{t}\right)=\sum_{i=1}^{I} \mu_{i} \sum_{\eta^{i, t}} \zeta_{t}^{i}\left(z^{t}, \eta^{i, t}\right)^{\frac{-1}{\alpha}} \pi\left(\eta^{i, t}\right) .
$$

Hence, the $-1 / \alpha^{\text {th }}$ moment of the multipliers summarizes risk sharing within this economy. The SDF is given by the Breeden-Lucas SDF and a multiplicative adjustment:

$$
m\left(z^{t+1} \mid z^{t}\right) \equiv \frac{P_{t+1}\left(z^{t+1}\right)}{P_{t}\left(z^{t}\right)}=\beta\left(\frac{C_{t+1}\left(z^{t+1}\right)}{C_{t}\left(z^{t}\right)}\right)^{-\alpha}\left(\frac{h_{t+1}\left(z^{t+1}\right)}{h_{t}\left(z^{t}\right)}\right)^{\alpha}
$$




\section{Law of Motion in $N F A_{t}$}

We aggregate the right hand side of aggregate budget constraint 13 .

$$
\begin{aligned}
& \sum_{j} A_{t}^{i, j}\left(z^{t}\right)+\gamma^{i} Y_{t}^{i}\left(z^{t}\right)-C_{t}^{i}\left(z^{t}\right) \\
= & R_{t}^{i}\left(z^{t}\right) N F A_{t-1}^{i}\left(z^{t-1}\right)+D_{t}^{i}\left(z^{t}\right)+V_{t}^{i}\left(z^{t}\right)+R_{t, t-1}^{f}\left(z^{t-1}\right) B_{t-1}^{i}\left(z^{t-1}\right)+\gamma^{i} Y_{t}^{i}\left(z^{t}\right)-C_{t}^{i}\left(z^{t}\right) \\
= & R_{t}^{i}\left(z^{t}\right) N F A_{t-1}^{i}\left(z^{t-1}\right)+\left(1-\gamma^{i}\right) Y_{t}^{i}\left(z^{t}\right)-R_{t, t-1}^{f}\left(z^{t-1}\right) B_{t-1}\left(z^{t-1}\right) \\
& +B_{t}\left(z^{t}\right)+V_{t}^{i}\left(z^{t}\right)+R_{t, t-1}^{f}\left(z^{t-1}\right) B_{t-1}^{i}\left(z^{t-1}\right)+\gamma^{i} Y_{t}^{i}\left(z^{t}\right)-C_{t}^{i}\left(z^{t}\right) \\
= & R_{t}^{i}\left(z^{t}\right) N F A_{t-1}^{i}\left(z^{t-1}\right)+B_{t}\left(z^{t}\right)+V_{t}^{i}\left(z^{t}\right)+Y_{t}^{i}\left(z^{t}\right)-C_{t}^{i}\left(z^{t}\right)
\end{aligned}
$$

The left hand side of country $i$ 's aggregate budget constraint is given by

$$
\begin{aligned}
& \sum_{z^{t+1} \succ z^{t}} \sum_{j} Q_{t}\left(z_{t+1}, z^{t}\right) \widehat{A}_{t+1}^{i, j}\left(z^{t+1}\right) \pi\left(z_{t+1} \mid z_{t}\right)+\sum_{j} S_{t}^{i, j}\left(z^{t}\right) V_{t}^{j}\left(z^{t}\right)+\sum_{j} B_{t}^{i, j}\left(z^{t}\right) \\
= & \sum_{z^{t+1} \succ z^{t}} \sum_{j \neq i} Q_{t}\left(z_{t+1}, z^{t}\right) \widehat{A}_{t+1}^{i, j}\left(z^{t+1}\right) \pi\left(z_{t+1} \mid z_{t}\right)+\sum_{j \neq i} S_{t}^{i, j}\left(z^{t}\right) V_{t}^{j}\left(z^{t}\right) \\
& +\sum_{j \neq i} B_{t}^{i, j}\left(z^{t}\right)+\sum_{z^{t+1} \succ z^{t}} Q_{t}\left(z_{t+1}, z^{t}\right) \widehat{A}_{t+1}^{i, i}\left(z^{t+1}\right) \pi\left(z_{t+1} \mid z_{t}\right)+S_{t}^{i, i}\left(z^{t}\right) V_{t}^{i}\left(z^{t}\right)+B_{t}^{i, i}\left(z^{t}\right) \\
= & F A_{t}^{i}\left(z^{t}\right)+V_{t}^{i}\left(z^{t}\right)+B_{t}^{i}\left(z^{t}\right)-F L_{t}^{i}\left(z^{t}\right)
\end{aligned}
$$

Finally, form Equation (20) and (21), we obtain the law of motion of net external account in counrty $i$

$$
\begin{aligned}
N F A_{t}^{i}\left(z^{t}\right) & \equiv F A_{t}^{i}\left(z^{t}\right)-F L_{t}\left(z^{t}\right) \\
& =R_{t}^{i}\left(z^{t}\right) N F A_{t-1}^{i}\left(z^{t-1}\right)+Y_{t}^{i}\left(z^{t}\right)-C_{t}^{i}\left(z^{t}\right) \\
& \equiv R_{t}^{i}\left(z^{t}\right) N F A_{t-1}^{i}\left(z^{t-1}\right)+N X_{t}^{i}\left(z^{t}\right)
\end{aligned}
$$

\section{First Two Moments of Output Growth Rate}

Our world consists of 48 countries. The data range is from 1980 to 2009 at annual frequency. The household consumption expenditure series $\left(C_{i t}\right)$ and the GDP deflator series $\left(P_{i t}\right)$ are from the International Monetary Fund's International Financial Statistics. The population series $\left(N_{i t}\right)$ 
is from the World Bank's World Development Indicators. The GDP share data are from the US Department of Agriculture's ERS Database. We calculate the world average of first two moments of growth rate of per capita real consumption in three steps.

First, we obtain the growth rate of real consumption per capita for each country: $g_{i t}=$ $c_{i t} / c_{i, t-1}-1$, where $c_{i t}=C_{i t} /\left(P_{i t} N_{i t}\right)$. Next, we calculate the standard deviation of $g_{i t}$ and denote it as $\sigma_{i}\left(g_{i t}\right)$. Finally, we calculate the weighted average of the country-specific standard deviation of growth of real consumption per capita using the GDP share as the weight. Let $\sigma\left(z_{t}\right)$ denote the world average standard deviation of country-specific growth rate of real consumption per capita. Hence,

$$
\sigma\left(z_{t}\right)=\sum_{i=1}^{48} w_{i} \sigma_{i}\left(g_{i t}\right)
$$

where $w_{i}=\sum_{t=1980}^{2009} w_{i, t} / 30$ and $w_{i, t}=G D P_{i, t} / \sum_{i=1}^{48} G D P_{i, t}$. Based on our data set, the average growth rate of consumption is $2.54 \%$ and its standard deviation is $3.02 \%$. 